\title{
Glacier changes between 1971 and 2016 in the Jankar Chhu Watershed, Lahaul Himalaya, India
}

\author{
SURESH DAS, MILAP CHAND SHARMA \\ Centre for the Study of Regional Development (CSRD), Jawaharlal Nehru University, New Delhi 110067, India \\ Correspondence: Suresh Das<suresh41_ssf@jnu.ac.in>
}

\begin{abstract}
Glacier changes in the Jankar Chhu Watershed (JCW) of Chandrabhaga (Chenab) basin, Lahaul Himalaya were worked out based on Corona and Sentinel 2A images between 1971 and 2016. The JCW consists of 153 glaciers $\left(>0.02 \mathrm{~km}^{2}\right)$ with a total area of $185.6 \pm 3.8 \mathrm{~km}^{2}$ that include 82 glaciers with debris-covered ablation zone, comprising $10.9 \%$ of the total glacierized area as in 2016 . Change analysis based on Corona (1971), Landsat (2000) and Sentinel 2A (2016) was restricted to 127 glaciers owing to the presence of cloud cover on 26 glaciers in 1971. A subset of glaciers was also mapped using Landsat Thematic Mapper (TM; 1989) image. The total glacier area decreased by $14.7 \pm 4.3 \mathrm{~km}^{2}(0.3 \pm$ $0.1 \mathrm{~km}^{2} \mathrm{a}^{-1}$ ). The number of glaciers in the JCW increased by four between 1971 and 2016 due to fragmentation. More recently (2000-16), recession rate has increased. Clean-ice area decreased by $21.8 \pm$ $3.8 \mathrm{~km}^{2}\left(0.5 \pm 0.1 \mathrm{~km}^{2} \mathrm{a}^{-1}\right)$ while debris-covered ice increased by $7.2 \pm 0.4 \mathrm{~km}^{2}\left(0.2 \pm 0.01 \mathrm{~km}^{2} \mathrm{a}^{-1}\right)$. Field observations of select glaciers also support derived recession trend in the JCW. Retreat rates in the JCW have been observed to be much lower than previously reported.
\end{abstract}

KEYWORDS: climate change, debris-covered glaciers, glacial geomorphology, glacier mapping, remote sensing

\section{INTRODUCTION}

The Hindu Kush-Karakoram-Himalayan $(\mathrm{HKH})$ region is the storehouse of fresh water of South Asia (Raina and Srivastava, 2008; Bajracharya and others, 2015). The glaciers of the Himalaya contribute significantly to the overall river runoff of south and southeast Asia (Basnett and others, 2013) with the highest contribution from the Indus River which originates in the northwest Himalaya (Immerzeel and others, 2010; Basnett and others, 2013). Himalayan glaciers have been in a general state of recession since 1850 (Mayewski and Jeschke, 1979; Bhambri and Bolch, 2009; Shukla and others, 2017), except for emerging indications of stability or mass gain in the Karakoram (Hewitt, 2005; 2011; Bolch and others, 2012; Bhambri and others, 2017). Recent comprehensive study by Bhambri and others (2017) reported that the number of surge-type glaciers in the Karakoram have increased significantly. This asymmetrical behavior of the Karakoram glaciers could be attributed to regional topography (Scherler and others, 2011a, b), regional climate (Bashir and others, 2017), glacier hypsometry (Gardelle and others, 2012; Brun and others, 2017), the characteristics and thickness of supraglacial debris cover (Scherler and others, 2011a) and their morphological properties (Salerno and others, 2017).

In the $\mathrm{HKH}$ region, a paucity of appropriate glacier data has prevented a comprehensive assessment of current regional mass balance (Bolch and others, 2012; Kääb and others, 2012). Multi-temporal and multi-spectral remotely sensed images are being used to detect changes in glacier area (Bhambri and others, 2011), length or terminus position (Bhambri and others, 2012), velocity (Kraaijenbrink and others, 2016) and thickness (Bolch and others, 2008) with large spatial scale at regular temporal intervals. Several interlinked global glaciers inventory initiatives exist, such as World Glacier Monitoring Service (WGMS; Haeberli and others, 1989), Global Land Ice Measurements from Space (GLIMS; Raup and others, 2007), GlobGlacier project (Paul and others, 2009), Randolph Glacier Inventory (RGl; Pfeffer and others, 2014), Glacier Area Mapping for Discharge in Asian Mountains (GAMDAM; Nuimura and others, 2015) and International Centre for Integrated Mountain Development (ICIMOD; Bajracharya and Shrestha, 2011; Bajracharya and others, 2015). However, none of the initiatives has resulted in an accurate and complete glacier inventory for the Himalayan region. Of all others, field investigation and measurement becomes an indispensable element of glaciology to overcome the uncertainties and speculations derived from the remotely sensed satellite datasets (Hubbard and Glasser, 2005).

Studies on glaciers located in the Western Himalaya (e.g. Beas, Chenab and Sutlej) have been done either using the Survey of India (Sol) topographical maps or coarser spatial resolution satellite datasets (Kulkarni and Alex, 2003; Kulkarni and others, 2007; Sharma and others, 2016; Brahmbhatt and others, 2017). However, several published works have registered inaccuracies in the portrayal of glacier outline on the Sol topographical maps of the 1960s (Bhambri and others, 2011; Chand and Sharma, 2015). It is further observed that on the coarser resolution satellite datasets (e.g. Landsat Multispectral Scanner), it is difficult to identify glacier terminus precisely, especially in the case of debris-covered glaciers (Chand and Sharma, 2015). The declassified imagery of Corona and Hexagon acquired in the 1960 s and the 1970 s provide great possibility to extract the historic glacier outlines for comparison with contemporary glacier outlines derived from satellite images (Schmidt and Nüsser, 2009, 2012, 2017; Bhambri and others, 2011; Chand and Sharma, 2015; Bhattacharya and others, 2016). Only a few studies exist on mapping and monitoring of glaciers for Chandrabhaga basin (Kulkarni and others, 2006; 
Negi and others, 2013; Pandey and Venkataraman, 2013; Birajdar and others, 2014; Garg and others, 2017a) while several studies have been published on mapping and change analysis of glaciers of the adjacent basins (Kamp and others, 2011; Schmidt and Nüsser, 2012, 2017; Chand and Sharma, 2015; Murtaza and Romshoo, 2016; Brahmbhatt and others, 2017; Chudley and others, 2017; Rashid and others, 2017; Patel and others, 2018). However, to the best of our knowledge, there is no published study on the Jankar Chhu Watershed (JCW) addressing glacier change in association with other variables (e.g. debris cover, topography and climate parameters). In addition, no studies exist that use declassified Corona images for glacier change analysis in the JCW. Thus the main goals of this study are to (i) generate a complete and up-to-date glacier inventory for the JCW, Chandrabhaga basin using Sentinel 2A (2016) images aided by high-resolution Google Earth (GE) images and limited field observation; (ii) analyze glacier area change in the JCW for 1971 (Corona), 2000 (Landsat) and 2016 (Sentinel 2A); and (iii) evaluate the possible impact of climate variables on glacier changes in the JCW.

\section{STUDY AREA}

The JCW is located in Lahaul and Spiti district of Himachal Pradesh, northern India. The total area of the JCW is 694.5 $\mathrm{km}^{2}$, where altitude varies from 3305 to $6309 \mathrm{~m}$ a.s.l. in the upper Chenab River system of the Greater Himalaya range (Fig. 1a). In the local language, 'Chhu' is the synonym of the small river. The Jankar Chhu is a tributary of Bhaga River and confluences at Darcha $\left(32^{\circ} 40^{\prime} \mathrm{N}\right.$ and $77^{\circ} 12^{\prime} \mathrm{E}$; $\sim 3313 \mathrm{~m}$ a.s.l.) (Fig. 1b). Chandra and Bhaga River flow together form Chandrabhaga (Chenab), which ultimately contributes to the Indus River system.

The climate of the study area is dominated by a long winter season from mid-November to March, with a spring season that lasts until the end of May (Owen and others, 1996). The region falls under the monsoon-arid transition zone. The region of Lahaul Himalaya is influenced by South Asian monsoon in the summer season and mid-latitudes westerlies in winter (Shehmani and others, 2015). The JCW has no climate observatory. Patsio $\left(32^{\circ} 45^{\prime} \mathrm{N} ; 77^{\circ}\right.$ $15^{\prime} \mathrm{E}$; $\sim 3774 \mathrm{~m}$ a.s.l.; 1983-present) in the Bhaga valley is the nearest representative observatory located at the southeast edge of the JCW (Fig. 1b), maintained and operated by the Snow Avalanche Study Establishment (SASE), Government of India. Sharma and others (2016) have reported that $\sim 80 \%$ of annual precipitation in Patsio is contributed through mid-latitude westerlies.

Field observations during 2015-17 of select glaciers show that large valley glaciers in the JCW are characterized by extensive supraglacial debris cover, crevasses, ice caves, lakes and glacial streams (Fig. 2). The terminus position has been measured at one point in the center of the terminus for five glaciers (see Fig. 1b for location) using a handheld
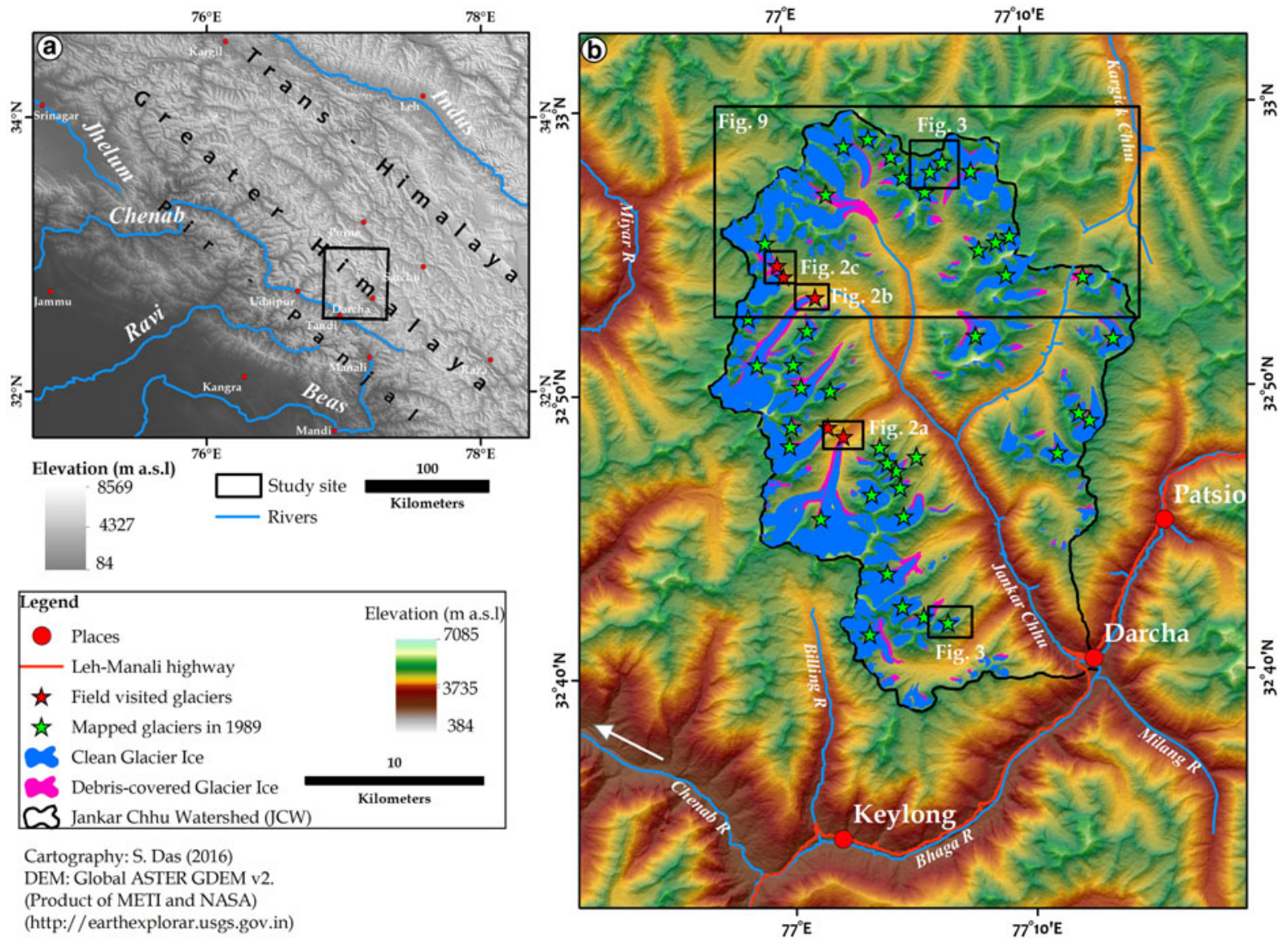

Fig. 1. (a) Location of study area in the Western Himalaya and in the upper Chenab River system of the Indian subcontinent. (b) Glacier coverage in the Jankar Chhu Watershed based on Sentinel 2A (1 November 2016) imagery; red and green stars represent field visited and mapped glaciers from Landsat TM (9 October 1989), respectively. 
a

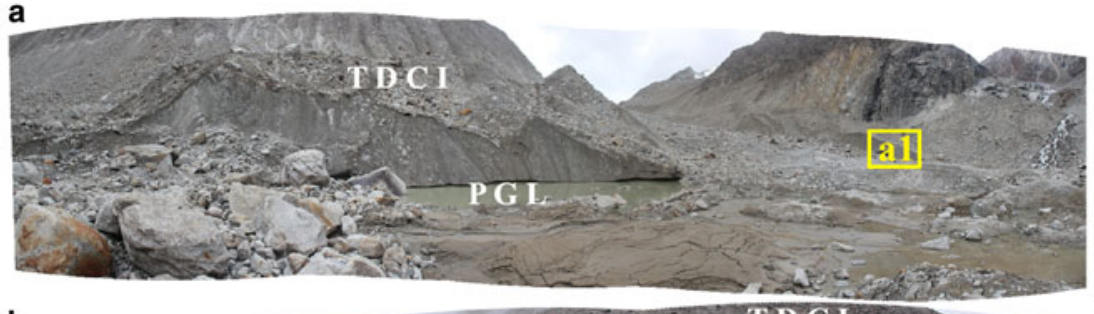

b

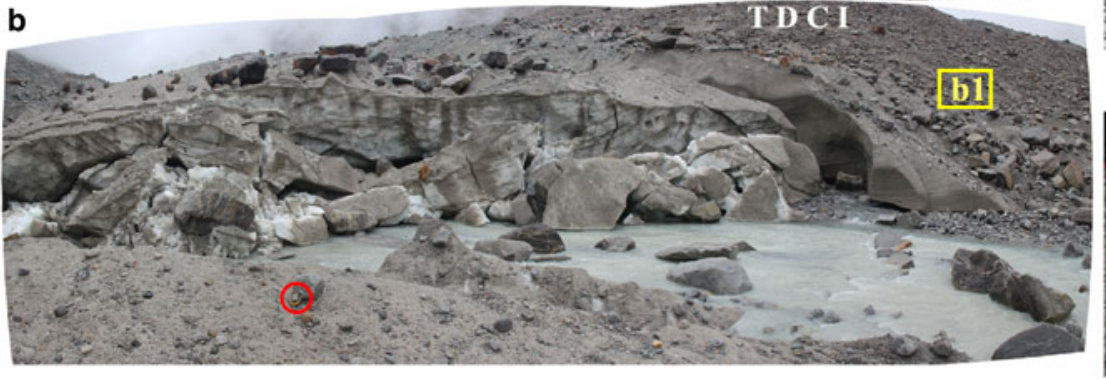

c
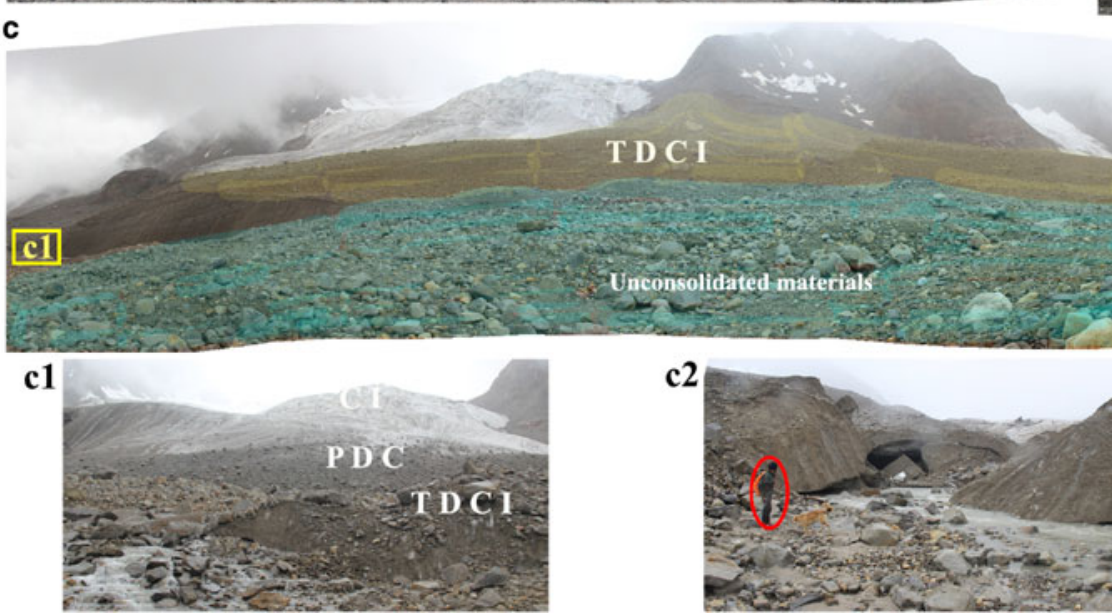

a1

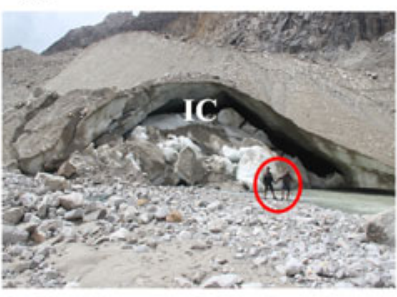

b1

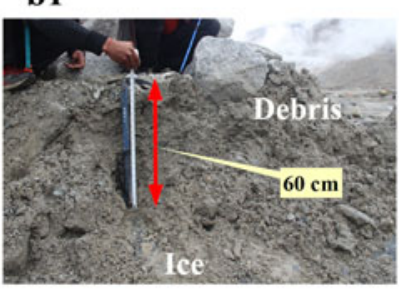

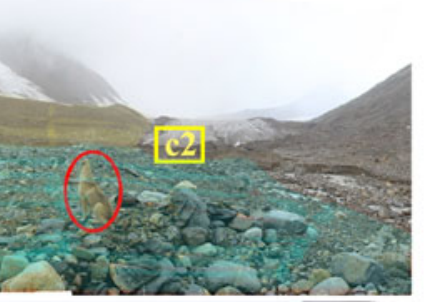

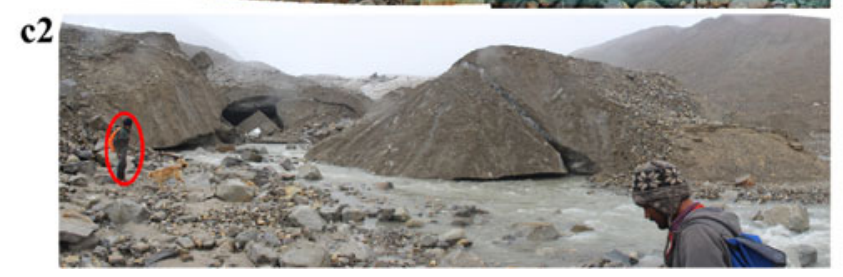

Fig. 2. Field photographs (2015-17) showing the terminus characteristics of select glaciers in the Jankar Chhu Watershed (see Fig. 1b for location). TDCl, thick debris-covered ice; PDC, partially debris-covered; $\mathrm{Cl}$, clean ice; IC, ice collapse; PGL, pro-glacial lake. The red circle and line represent the scale of the image.

GPS (Garmin etrex10 with $\pm 5-10 \mathrm{~m}$ horizontal accuracy). Field measurement reveals that debris thickness on glaciers varies from 5 to $60 \mathrm{~cm}$ (Fig. 2b).

\section{DATA SOURCES}

Glacier mapping, inventory and change analysis were carried out for the JCW, Chandrabhaga basin, Lahaul
Himalaya from various temporal, multi-spectral and medium to high-resolution satellite image sources (Table 1). The Corona (KH-4B) images of 1971, with minimal seasonal snow cover as well as cloud cover acquired from the United States Geological Survey (USGS; http://earthexplorer.usgs.gov/), were used to extract the extent of baseline glacier boundaries in the JCW. Multi-spectral orthorectified Sentinel 2A (2016), Landsat Thematic

Table 1. Satellite data and Digital Elevation Model (DEM) used in this study

\begin{tabular}{|c|c|c|c|c|c|c|}
\hline Date of acquisition & Satellite/sensor & Scene/product/path and row ID & $\begin{array}{l}\text { Spatial } \\
\text { resolution }(\mathrm{m})\end{array}$ & $\begin{array}{l}\text { Spectral } \\
\text { bands }\end{array}$ & $\begin{array}{l}\text { No. of } \\
\text { GCPs }\end{array}$ & $\begin{array}{c}\text { RMSE } \\
(\mathrm{m})\end{array}$ \\
\hline 28 September 1971 & CORONA/KH $-4 \mathrm{~B}^{*}$ & $\begin{array}{l}\text { 70MM DS1115-2282DF058 } \\
\text { 70MM DS1115-2282DF059 } \\
\text { 70MM DS1115-2282DF060 }\end{array}$ & $\begin{array}{l}\sim 1.8 \mathrm{~m} \text { in } \\
\text { the center }\end{array}$ & Pan & $\begin{array}{r}40 \\
275 \\
320\end{array}$ & $\begin{array}{l}<6 \\
<6 \\
<6\end{array}$ \\
\hline 9 October 1989 & Landsat $5 \mathrm{TM}^{*}$ & ETP147R37_5T19891009 & 30 & VIS + MIR & $79 * *$ & $<15$ \\
\hline 15 October 2000 & Landsat 7 ETM+* & LE71470372000289SGS00 & $\begin{array}{l}15 \\
30\end{array}$ & Pan VIS + MIR & $216 \#$ & $<15$ \\
\hline 01 November 2016 & Sentinel $2 \mathrm{~A} \mathrm{MSI}^{*} \#$ & $\begin{array}{l}\text { L1C_TL_SGS_20161002T104830 } \\
\text { _A006680_T43SFS }\end{array}$ & $\begin{array}{l}10 \\
20\end{array}$ & VIS SWIR & & Base image \\
\hline 17 October 2011 & ASTER GDEM v2+ & $\begin{array}{l}\text { ASTGTM2_N32E076 } \\
\text { ASTGTM2_N32E077 }\end{array}$ & 30 & & & \\
\hline
\end{tabular}

\#Radio-metrically corrected and orthorectified images; **radio-metrically corrected; *data downloaded from http://earthexplorer.usgs.gov; +ASTER GDEM (Advanced Spaceborne Thermal Emission and Reflection Radiometer Global Digital Elevation Model) is a product of the Ministry of Economy, Trade, and Industry of Japan (METI) and the National Aeronautics and Space Administration (NASA). GCPs, ground control points; RMSE, root-mean-square error; Pan, panchromatic; KH-4B: keyhole-4B; TM: Thematic Mapper; ETM: Enhanced Thematic Mapper; MSI: multispectral instrument; VIS: visible; IR: infrared; TR: thermal; MIR, mid-infrared; SWIR, shortwave infrared. 
Mapper (TM; 1989) and Enhanced Thematic Mapper Plus (ETM+; 2000) satellite images were acquired from USGS in the Universal Transverse Mercator (UTM) Zone 43 World Geodetic System (WGS) 84 projection (Table 1). Sentinel $2 \mathrm{~A}$ and Landsat images were specifically obtained under (or nearly) cloud-free conditions at the end of ablation season. The Advanced Spaceborne Thermal Emission Reflection Radiometer Global Digital Elevation Model Version 2 (ASTER GDEM v2) was used as reference DEM for semi-automatic delineation of drainage basins and extraction of topographic parameters of the glacier (Table 1).

\section{METHODS}

\section{Rectification of satellite images}

Owing to the difficult geometry of the Corona imagery (Schmidt and Nüsser, 2012; Bhambri and others, 2011, 2012), three subsets of three Corona forward strips were generated in the present study. All subsets were co-registered based on two operational approaches suggested by Bolch and others (2010b): (1) projective transformation was performed based on ground control points (GCPs) and the ASTER GDEM using ERDAS Imagine 14; followed by (2) spline adjustment using ESRI ArcGIS 10.2.2. Prominent peaks and junctions between streams and roads were used for GCPs assuming no changes occurred for these points on the ground during the observation period. For each Corona subset, 40-320 GCPs were acquired from Sentinel 2A imagery (2016) for co-registration. We concentrated on the adjustment of the area around the glaciers in Corona images with respect to the base image (2016) for consistency of results during rectification (Bolch and others, 2010b; Bhambri and others, 2011). In addition, to assess positional accuracy, 30 common points (e.g. confluence of ridges and road junctions) were carefully identified in each Corona subset and Sentinel 2A image. The horizontal shift of three Corona images was calculated at $\pm 5.6, \pm 5.4$ and $\pm 6.2 \mathrm{~m}$ to base image (Sentinel 2A) (Table 1).

The Landsat ETM+ image of 2000 is available in the processing level L1T (radio-metrically calibrated and orthorectified using GCPs and DEM) and Landsat TM image of 1989 processed to L1G (radio-metrically calibrated and nonorthorectified) (Tucker and others, 2004). Both Landsat images show a horizontal shift of $\sim 30 \mathrm{~m}$ as compared with 2016 base image (Sentinel 2A). In addition, Landsat ETM+ comes with a panchromatic band (band 8; 0.5-0.9 $\mu \mathrm{m}$ ) with spatial resolution of $15 \mathrm{~m}$. Bands $1-5$ and band 6 of the Landsat ETM+ (2000) were pan-sharpened to $15 \mathrm{~m}$ using Brovey transformation image fusion technique with panchromatic band (Chand and Sharma, 2015). This helps in identifying terminus position and other morphological features (e.g. debris-covered ice, supraglacial ponds, etc.). Landsat TM (1989) and pan-sharpened ETM+ (2000) imagery were coregistered to the base image (Sentinel 2A) using projective transformation as discussed earlier. Thirty common points were identified in Landsat TM (1989), pansharpened ETM+ (2000) and base image (Sentinel 2A) to assess the positional accuracy. The horizontal shift between the base image and Landsat pan-sharpened ETM+ and TM was measured at $\sim 10.5 \mathrm{~m}(\sim 0.7$ pixels $)$ and $\sim 11.6$ $\mathrm{m}(\sim 0.4$ pixels), respectively. Sentinel $2 \mathrm{~A}$ image was processed in two steps. At first, visible and near-infrared bands were stacked using layer stacking tool in ERDAS Imagine
14. Later, shortwave infrared band 2 (SWIR2; band 12; 20 $\mathrm{m}$ spatial resolution) was resized to $10 \mathrm{~m}$ with the stacked band in ERDAS Imagine 14.

\section{Glacier mapping and inventory}

Glacier outlines were manually delineated from 1971 Corona images (Fig. 3a). For Landsat TM (1989) and pansharpened ETM+ imagery (2000), glaciers were manually mapped using mid-infrared-red-green bands (Fig. 3b). Bands SWIR2-red-green were used for glacier boundary delineation from 2016 Sentinel 2A image (Fig. 3c). The minimum size of mapped glaciers included in our inventory is $0.02 \mathrm{~km}^{2}$ as per Bajracharya and Shrestha (2011) and Frey and others (2012). Manual on-screen mapping was done despite having advantages of automated band ratio techniques (Paul and others, 2009, 2013) as the relative error strongly increases with decreasing glacier area (Paul and others, 2013; Fischer and others, 2014) and with the presence of debris cover (Bolch and others, 2008; Racoviteanu and others, 2008; Frey and others, 2012). Paul and others (2013) have shown that the bias significantly increases for glaciers with an area $<1 \mathrm{~km}^{2}$ in size, which constitutes $\sim 77.3 \%$ of all glaciers in the JCW in 2016, reducing the advantage of automatic techniques. It is important to differentiate between snow packs and small glaciers $\left(<0.5 \mathrm{~km}^{2}\right.$ in size) as some snow packs can sustain for several years. Multi-temporal historical images (e.g. Corona, Landsat) were used to differentiate between these. Several signs of movement (based on overlays of multi-temporal images) such as issuing meltwater streams at the end of the terminus, breaks in surface slope, spectral color differences and the presence of small meltwater ponds were employed for identification of the most likely position of the glacier termini in the study (Bhambri and others, 2011; Chand and Sharma, 2015). To assist manual delineation of debris-covered terminus in 2016, imagery from GE was used as an additional source in combination with the Sentinel 2A image. Field mapping and photographs also facilitated the determination of glacier termini during 2015-17. Ice and snow areas directly above bergschrunds were not included in the glacier outlines (cf. Racoviteanu and others, 2009; Bhambri and others, 2011). In addition, digitized glacier boundaries from Sentinel 2A image were exported to GE for cross-checking and manual correction.

The contiguous ice masses were separated into entities on the basis of the generated watershed (Racoviteanu and others, 2009; Schmidt and Nüsser, 2012), extracted from ASTER GDEM v2 by using the Hydrology Tool in ArcGIS 10.2.2, and further checked and corrected in GE using the 3 -D view. The separated glacier areas were transformed to vector data for automatic calculation of glacier size and topographic parameters (e.g. elevation, slope, aspect) (Schmidt and Nüsser, 2012). The characteristics of glacier distribution were examined by statistically analyzing the relations between topographic parameters and glacier area (Svoboda and others, 2009). Each glacier polygon $>0.02 \mathrm{~km}^{2}$ was further labelled by corresponding number (Supplementary Figure S1) and categorized as valley, cirque, plateau, hanging, simple (mountain) basin and compound (valley) basin glacier (Supplementary Figure S2) based on Bajracharya and Shrestha (2011) as well as Schmidt and Nüsser (2012). 

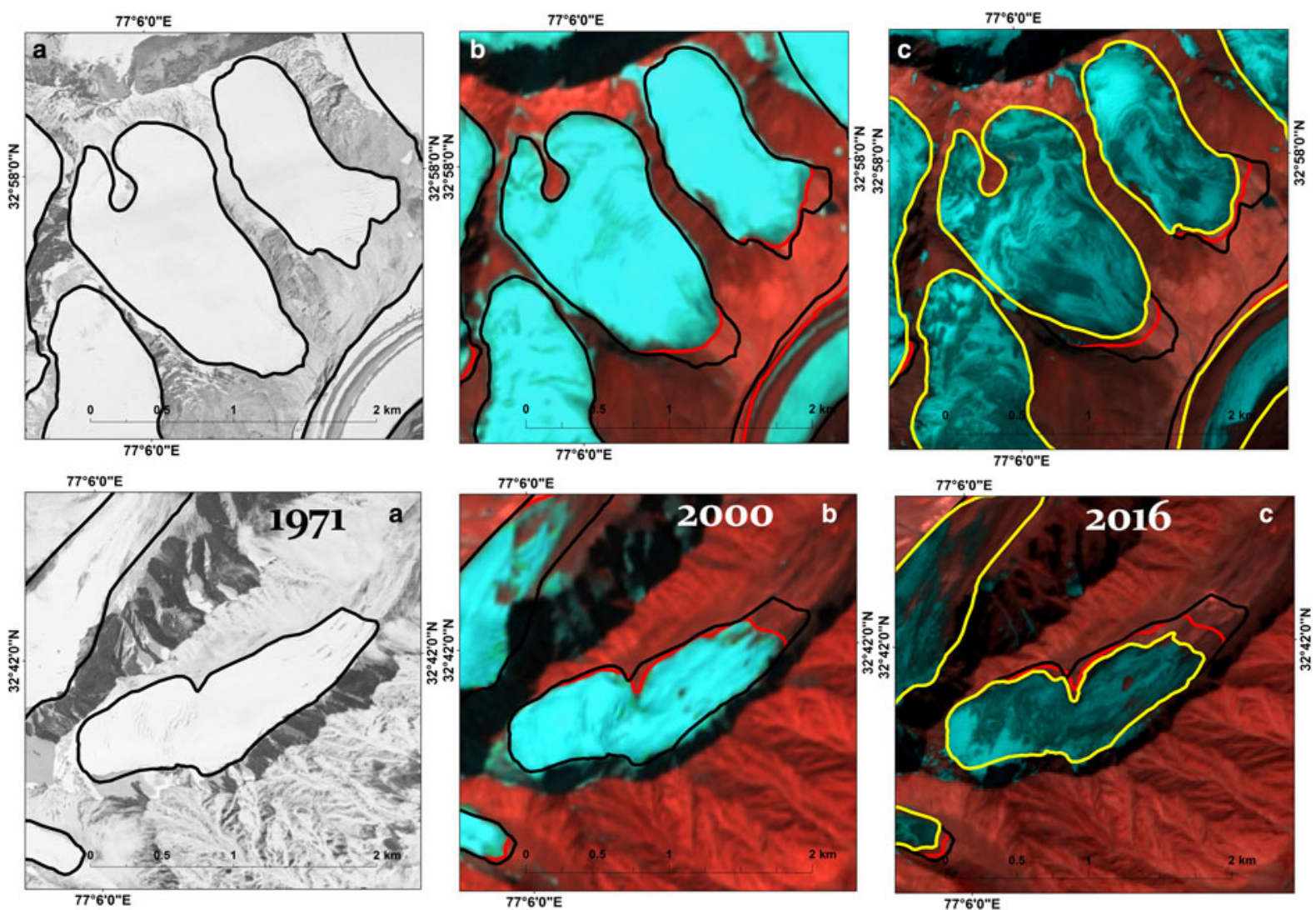

Fig. 3. Satellite images of two sets of glaciers in the Jankar Chhu Watershed, Lahaul Himalaya (see Fig. $1 \mathrm{~b}$ for location). (a) A rectified subset of Corona image (28 September 1971) based on projective transform and spline method with similar year glacier outline. (b) Coregistered Landsat pan-sharpened ETM+ image (15 October 2000) based on projective transform with Corona and Landsat ETM + glacier outlines. (c) Sentinel 2A image (1 November 2016) with Corona, Landsat ETM+ and Sentinel 2A glacier outlines.

\section{Change detection analyses}

For glacier change measurements and quantification, the glacier outlines of 2016 were overlaid on Corona images (1971) as suggested by previous studies (Bolch and others, 2010a, b; Bhambri and others, 2011). Overlay adjustments were restricted to the lower part of the analyzed 127 glaciers. The upper accumulation region exhibits no visible changes during the study period (Fig. 3). The area of exposed rocks in the upper section of glaciers was mapped and the calculated area was deducted from the total glaciated area, considering that the ice was lost from these rock faces. For glaciers that fragmented between 1971 and 2016, the combined area was recorded. A bi-temporal comparison between 1971 and 2016 as well as decadal change analyses were carried out for two distinct time span: 1971-2000 and 2000-2016 only for 127 selected glaciers. The rest of the glaciers were obscured by cloud mask on the available Corona images (1971). The Landsat TM scene (1989) had extensive snow cover, and only the glaciers with least seasonal snow cover in the ablation zone were mapped. Therefore, a subset of 41 glaciers out of 127 glaciers was computed for change detection for three distinct time period: 1971-1989, 1989-2000 and 2000-2016. The glacier subset (41) is considered representative as its members are in different size classes between 0.2 and $22.1 \mathrm{~km}^{2}$ (2016) and elevation ranges from 4363 to $6081 \mathrm{~m}$ a.s.l.

\section{Mapping uncertainty}

Potential errors in this study arise through the image registration, digitization process and with difficulties in correctly identifying the areas of glacier ice. We estimated the mapping uncertainty for each glacier based on a buffer size of $5 \mathrm{~m}$ (half of a pixel) for the base image (Sentinel 2A (2016)), and a buffer size of half of the estimated shift (see Table 1: RMSE) caused by misregistration of multi-temporal images to the base image (cf. Granshaw and Fountain, 2006; Bolch and others, 2010a, b). This method includes the relative higher error of small glaciers as these have relatively more edge pixels (Bolch and others, 2010a). Another way to assess the accuracy of glacier boundary extraction via low to medium-resolution images is to compare the extracted boundaries with higher resolution satellite image (Paul and others, 2002, 2013). In addition, higher resolution imageries available in GE were taken as reference for accuracy checks. Comparison of outlines for 30 select glaciers derived from Sentinel 2A and GE yields an uncertainty of $\pm 0.9 \mathrm{~km}^{2}(\sim 0.6 \%)$ (Supplementary Table S1). The final mapping uncertainty was $\sim 2.1 \%$ for Sentinel 2A (2016), $\sim 2.4 \%$ and $\sim 2.9 \%$ for Landsat TM (1989) and pan-sharpened ETM+ (2000) image, respectively, and $\sim 1.2 \%$ for Corona (1971). The area change uncertainty was estimated according to standard error propagation, as root sum square of the uncertainty for outlines mapped from different sources (Bhambri and others, 2011). The resultant uncertainties are within the range 
reported by earlier studies (Bhambri and others, 2011; Paul and others, 2013).

\section{RESULTS}

\section{Glacier inventory and characteristics}

In 2016, 153 glaciers larger than $0.02 \mathrm{~km}^{2}$ were mapped in the study area covering an area of $185.6 \pm 3.8 \mathrm{~km}^{2}$ (Table 2a). Of these, 81 glaciers are debris-covered (Table 2a). Morphological type and spatial distribution of glacier size classes are presented in Figure 4. A range of small plateau to large valley glaciers are identified in the $\mathrm{JCW}$, ranging from 0.02 to $21.7 \mathrm{~km}^{2}$ in size (Table $2 \mathrm{~b}$; Fig. 5). The mean glacier size $\left(1.2 \mathrm{~km}^{2}\right)$ in the JCW is similar to the other glaciated basins of the Himalayan region, e.g. Ravi $\left(0.6 \mathrm{~km}^{2}\right)$, Shyok $\left(1.4 \mathrm{~km}^{2}\right)$, Ladakh $\left(1 \mathrm{~km}^{2}\right)$, Chenab $\left(1.1 \mathrm{~km}^{2}\right)$, Bhagirathi $\left(1.3 \mathrm{~km}^{2}\right)$, Saraswati/ Alaknanda basin $\left(3.7 \mathrm{~km}^{2}\right)$, Ganga $\left(1.1 \mathrm{~km}^{2}\right)$ and Brahmaputra $\left(1.2 \mathrm{~km}^{2}\right)$ (Bhambri and others, 2011; Frey and others, 2012; Schmidt and Nüsser, 2012; Bajracharya and others, 2014; Chand and Sharma, 2015). Debriscovered ice area in the JCW $(\sim 11 \%)$ is comparatively lower than the other basins of Western Himalaya (average of all basins $~ 15 \%$ ) (Frey and others, 2012). Small glaciers $\left(<1 \mathrm{~km}^{2}\right.$ in size) show a higher percentage $(\sim 15 \%)$ of debris-covered ice as compared with large glaciers $(>5$ $\mathrm{km}^{2}$ in size; $10 \%$ ) (Table 2a).

Compound (valley) basin glaciers have the highest amount of debris-covered ice ( 17\%), while hanging glaciers are debris-free (Table $2 \mathrm{~b}$ ). In total, $77 \%$ of all glaciers have areas $<1 \mathrm{~km}^{2}$, covering $\sim 17.5 \%$ of the total glacierized area (Table 2a; Fig. 5). Small glaciers (e.g. cirque, plateau and hanging) are dominant in numbers while large glaciers (e.g. valley and mountain basin combinedly) cover $\sim 55.2 \%$ of total glacierized area and $\sim 6.6 \%$ of all glaciers (Table 2b; Fig. 5).

The distribution of glacierized area by elevation (i.e. hypsometry) of total glaciers, clean-ice, debris-covered ice surface, sorted by glacier size classes and according to morphological type is provided in Figure 6. Most of the glaciers in different size classes are distributed between 5200 and $5400 \mathrm{~m}$ a.s.l. with smaller glaciers generally at a higher elevation compared with larger glaciers (Table 2a; Fig. 6a). Glaciers $>10 \mathrm{~km}^{2}$ in size (ranging from 13.4 to $21.7 \mathrm{~km}^{2}$ ) are mainly concentrated below $5400 \mathrm{~m}$ a.s.l. Valley glaciers are mainly confined below $5400 \mathrm{~m}$ a.s.l., while small glaciers (i.e. plateau and hanging) are distributed above $5400 \mathrm{~m}$ a.s.l. (Table 2b; Fig. 6b).

Mean altitude of glacier ranges from 4843 to $6237 \mathrm{~m}$ a.s.l., with an average of $5373 \mathrm{~m}$ a.s.I. (Table 2a; Fig. 7a). Mean elevation $(\sim 5373 \mathrm{~m})$ of glaciers in the JCW is similar to that of the Central and Western Himalayan basins like Kang Yatze (5710 m), central Ladakh range (5497 m), Alaknanda (5380 m), Bhagirathi (5544 m), Yamuna (5083 m), Sutlej $(5436 \mathrm{~m})$, Chenab (5064 m), Indus (5404 m) and Shyok $(5868 \mathrm{~m})$ (Frey and others, 2012; Schmidt and Nüsser, 2017). Elevation range varies according to glacier size class (Table 2; Fig. 7b).

The mean slope of all glaciers is $24^{\circ}$ (Table 2a), with smaller glaciers being steeper (Fig. 7c) and the slope of hanging and plateau glaciers is almost twice that of valley glaciers (Table $2 \mathrm{~b}$; Fig $7 \mathrm{c}$ ). Most glaciers $(\sim 30 \%$, or $\sim 26 \%$ of the area) have northwest aspect (Table 2a; Fig. 8a). Glacier size class distribution according to aspect shows that $\sim 50 \%$ of glaciers $\left(>10 \mathrm{~km}^{2}\right)$ are oriented toward the east (Table 2a; Fig. 8b). Valley glaciers are mainly oriented toward the east $(\sim 29 \%)$ and southwest $(\sim 29 \%)$, while the maximum number $(\sim 87 \%)$ of small hanging glaciers are oriented toward the south (Table 2b; Fig. 8c).

Table 2. Derived glacier parameters (2016) for the Jankar Chhu Watershed based on Sentinel 2A and ASTER GDEM v2

(a) Glacier parameters derived according to glacier size class

$\begin{array}{ll}\text { Parameters } & \text { JCW } \\ \text { Average elevation mean }(\mathrm{m} \text { a.s.I.) } & 5373 \\ \text { Average elevation range }(\mathrm{m}) & 420 \\ \text { Minimum elevation (m a.s.l.) } & 4363 \\ \text { Maximum elevation (m a.s.I.) } & 6309 \\ \text { Mean slope }\left({ }^{\circ}\right) & 24 \\ \text { Aspect } & \mathrm{N} \\ \text { Number of glaciers } & 153 \\ \text { DC glacier area }\left(\mathrm{km}^{2}\right) & 20.3(10.9 \%) \\ \text { Cl glacier area }\left(\mathrm{km}^{2}\right) & 165.2(89.1 \%) \\ \text { Total glacierized } \mathrm{area}^{\left(\mathrm{km}^{2}\right)} & 185.6\end{array}$

(b) Glacier parameters derived according to glacier type

\begin{tabular}{|c|c|c|c|c|c|c|}
\hline \multicolumn{7}{|c|}{ Morphological types } \\
\hline & Valley & Cirque & Plateau & Hanging & Simple basin & Compound basin \\
\hline Average elevation mean ( $\mathrm{m}$ a.s.I.) & 5318 & 5288 & 5607 & 5724 & 5267 & 5262 \\
\hline Average elevation range $(\mathrm{m})$ & 1288 & 398 & 261 & 214 & 410 & 1130 \\
\hline Minimum elevation (m a.s.l.) & 4363 & 4797 & 4740 & 5324 & 4689 & 4667 \\
\hline Maximum elevation (m a.s.l.) & 6081 & 6176 & 6309 & 6069 & 6146 & 5998 \\
\hline Mean slope $\left(^{\circ}\right)$ & 17 & 21 & 31 & 30 & 22 & 17 \\
\hline Aspect & $\mathrm{S}$ & NW & SE & $\mathrm{S}$ & NE & $\mathrm{N}$ \\
\hline Number of glaciers & $7(4.6 \%)$ & $43(28.1 \%)$ & $35(22.9 \%)$ & $7(4.6 \%)$ & $58(38 \%)$ & $3(2 \%)$ \\
\hline DC glacier area $\left(\mathrm{km}^{2}\right)$ & $8.9(10.6 \%)$ & $3.4(11 \%)$ & $0.5(10.6 \%)$ & & $4.2(8.9 \%)$ & $3.2(17.1 \%)$ \\
\hline $\mathrm{Cl}$ glacier area $\left(\mathrm{km}^{2}\right)$ & $74.7(89.4 \%)$ & $27.4(89 \%)$ & $4.2(89.4 \%)$ & $0.7(100 \%)$ & $42.8(91.1 \%)$ & $15.5(82.9 \%)$ \\
\hline Mean size $\left(\mathrm{km}^{2}\right)$ & 11.6 & 0.7 & 0.1 & 0.1 & 0.8 & 6.2 \\
\hline Total glacierized area $\left(\mathrm{km}^{2}\right)$ & $83.7(45.1 \%)$ & $30.8(16.6 \%)$ & $4.7(2.5 \%)$ & $0.7(0.4 \%)$ & $47(25.3 \%)$ & $18.7(10.1 \%)$ \\
\hline
\end{tabular}

(a) Glacier parameters derived according to size class $\left(\mathrm{km}^{2}\right)$. (b) Glacier parameters derived according to glaciers type. Cl, clean ice; DC, debris-covered ice. 

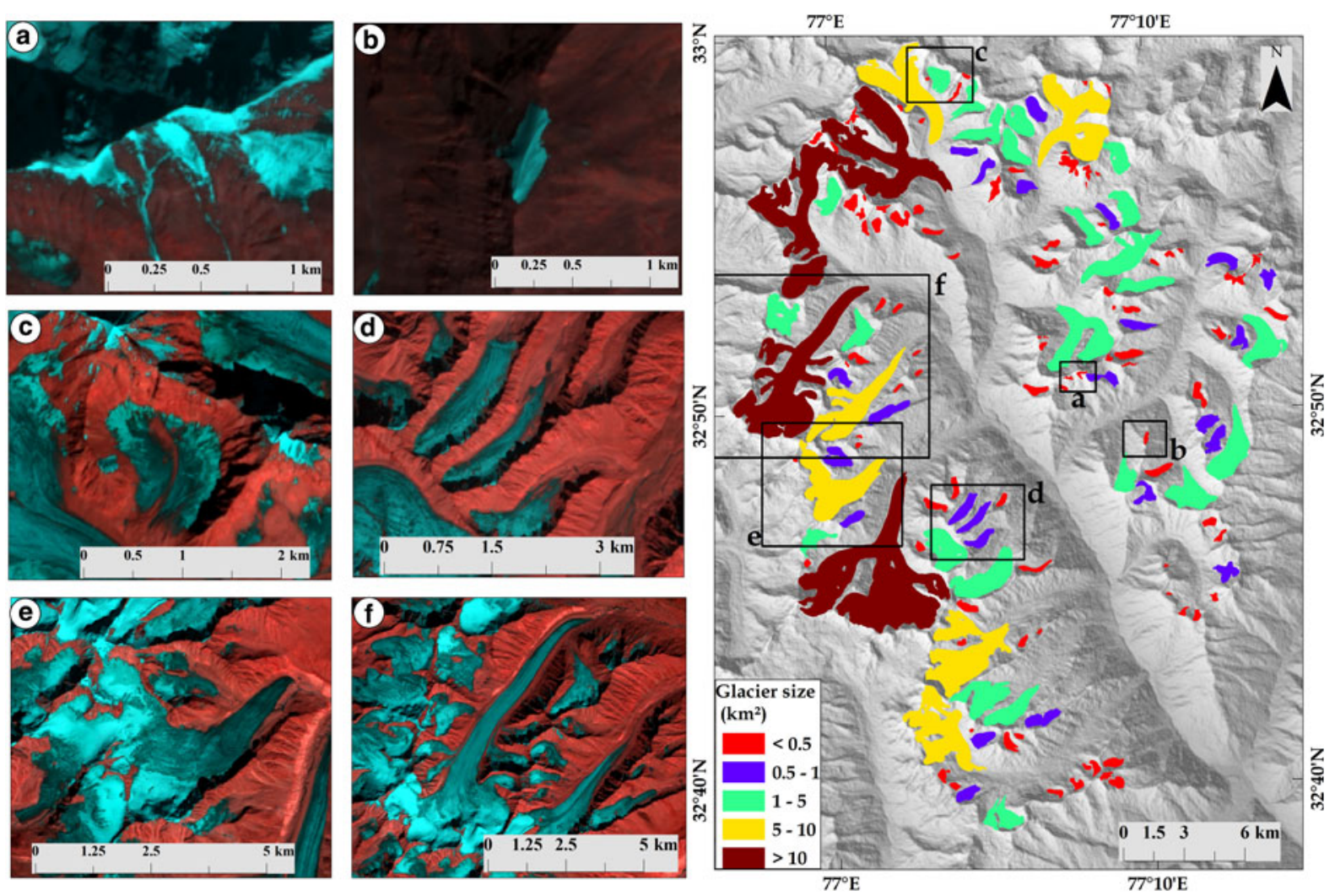

Fig. 4. Glacier types (left) and sizes (right) in the Jankar Chhu Watershed, Lahaul Himalaya in 2016. (a) Hanging glacier with clean ice. (b) Plateau glacier. (c) Cirque glacier with partly debris-covered ice. (d) Simple (mountain) basin glacier with partly debris-covered ice. (e) Compound (valley) basin glacier. (f) Valley glaciers with multiple tributary glaciers and partially debris-covered ice in ablation zone. The background image is Sentinel 2A (12-4-3 bands) (left) and shaded relief map from ASTER GDEM v2 (right).

\section{Glacier change detection}

Glacier area has been lost at heterogeneous rates since 1971 in the JCW (Supplementary Table S2). An example of glacier area change in the JCW is illustrated in Figure 9. During the observation period (1971-2016), glacier area changed from $196.0 \pm 2.3 \mathrm{~km}^{2}$ (1971) to $181.4 \pm 3.6 \mathrm{~km}^{2}$ (2016), a decrease of $7.5 \pm 2.2 \%\left(0.2 \pm 0.1 \% \mathrm{a}^{-1}\right) \quad($ Table $3 a)$. The number of analyzed glaciers increased from 127 (1971) to 131 (2016) due to the fragmentation. The loss in glacier area ranged from 1.3 to $52.1 \%$ from 1971 to 2016 (Supplementary Table S2). Clean-ice glacier area decreased from $183.4 \pm 2.1 \mathrm{~km}^{2}$ (1971) to $161.6 \pm 3.2 \mathrm{~km}^{2}$ (2016), a decrease of $11.9 \pm 2 \%$ (Table 3a). Debris-covered ice

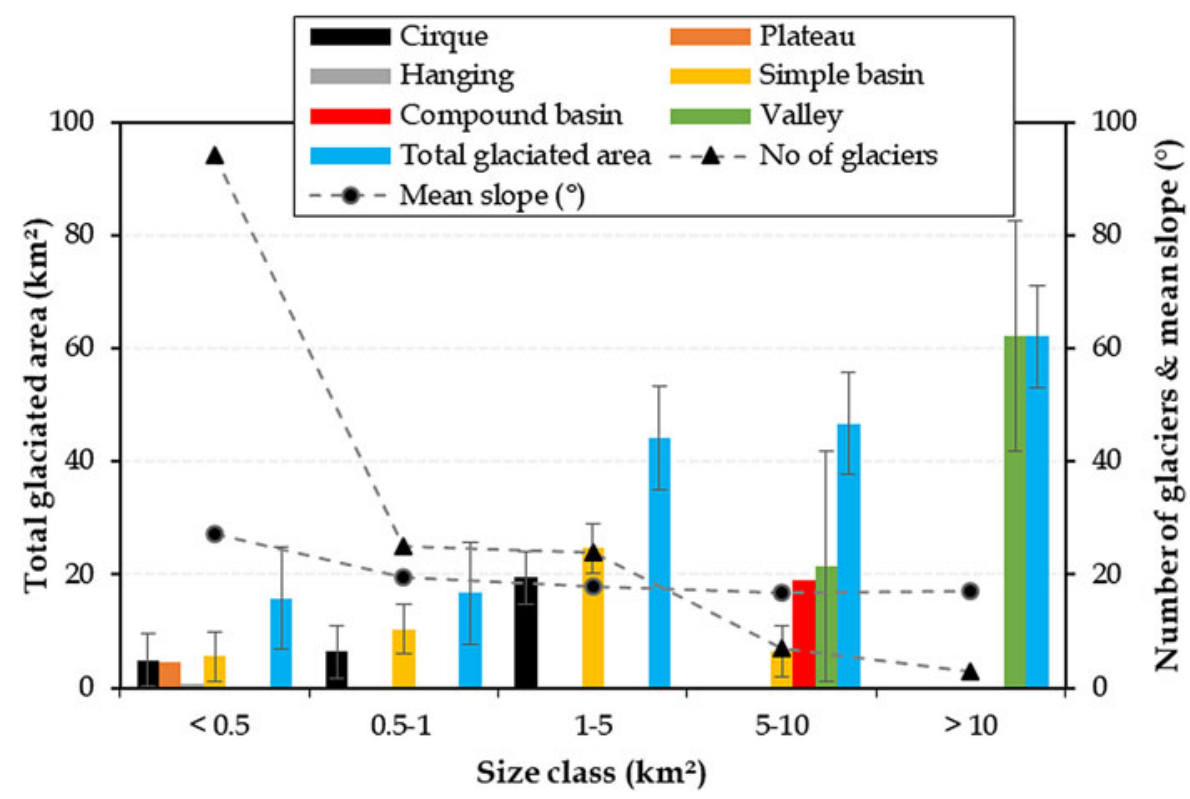

Fig. 5. Distribution of number of glaciers, glacier area as per size class and morphological type in the Jankar Chhu Watershed. Glacier area and morphological types were derived from Sentinel 2A image (2016) and ASTER GDEM v2. 


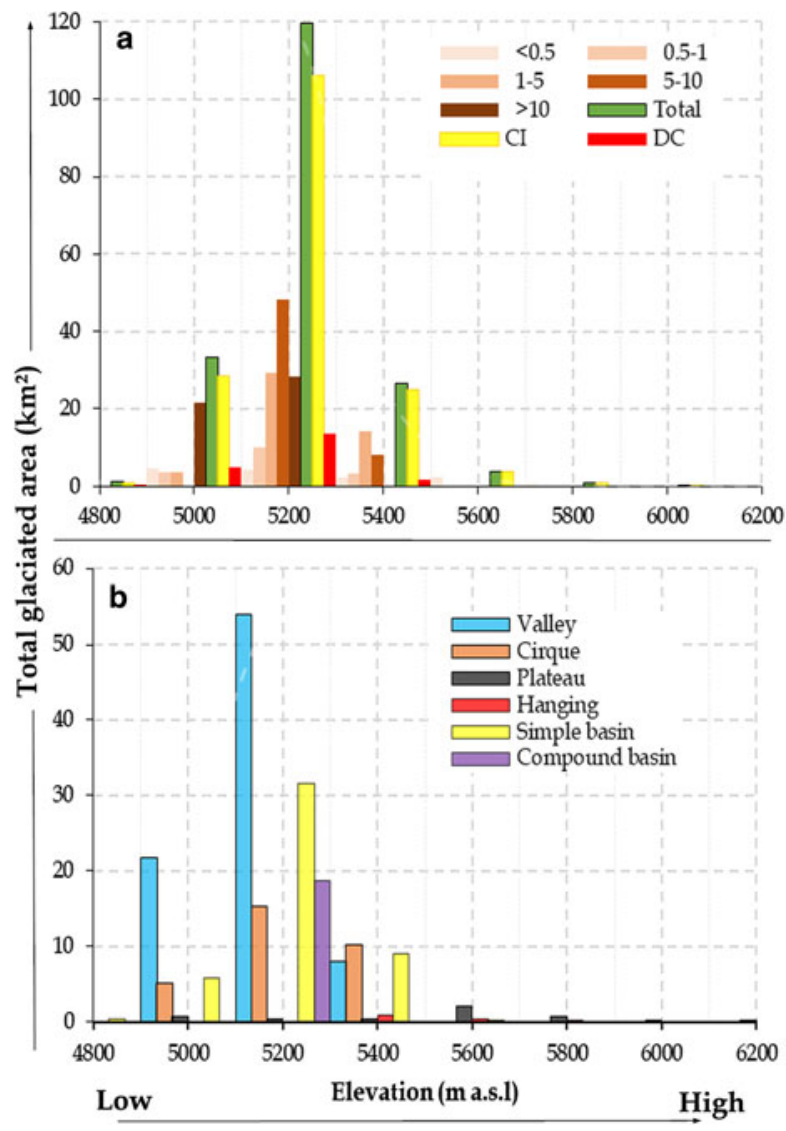

Fig. 6. Distribution of glaciated area in relation to altitudinal zones in the Jankar Chhu Watershed. (a) Hypsometry of clean ice $(\mathrm{Cl})$, debris-covered ice (DC), total glaciated area (Total) and glaciated area according to different size classes in 2016. (b) Distribution of glacier according to elevation zone and morphological types in 2016. Glacier area and elevation data were derived from Sentinel 2A (1 November 2016) and ASTER GDEM v2.

increased from $12.6 \pm 0.2 \mathrm{~km}^{2}(1971)$ to $19.8 \pm 0.4 \mathrm{~km}^{2}$ (2016), an increase of $56.8 \pm 3.3 \%$ (Table 3a). Out of 127 glaciers, 61 glaciers were covered with debris in 1971 which increased to 76 by 2016 (Table 3a). The spatial distribution map of relative area change indicates that most of the analyzed glaciers lost area below 10\% rate between 1971 and 2016 (Fig. 10).

Decadal glacier area change was examined in detail for 41 mapped glaciers (1989) (Table 3b). These glaciers (41) lost $2.2 \pm 3.9 \mathrm{~km}^{2}\left(1.3 \pm 2.4\right.$ or $\left.0.1 \pm 0.1 \% \mathrm{a}^{-1}\right)$ of their area from 1971 to $1989,2.4 \pm 5.2 \mathrm{~km}^{2}(1.5 \pm 3.2$ or $0.14 \pm 0.3 \%$ $\left.\mathrm{a}^{-1}\right)$ from 1989 to 2000 and $4.8 \pm 4.6 \mathrm{~km}^{2}(3.0 \pm 2.9$ or 0.2 $\pm 0.1 \% \mathrm{a}^{-1}$ ) from 2000 to 2016 . Analysis indicates that glacier recession has slightly increased in recent decades (2000-2016) as compared with 1971-1989 (Table 3b).

Glaciers between 0.5 and $1 \mathrm{~km}^{2}$ in size lost maximum area $\left(21.3 \pm 2\right.$ or $\left.0.5 \pm 0.1 \% \mathrm{a}^{-1}\right)$ from 1971 to 2016 (Table 4; Fig. 11a). Glaciers $>10 \mathrm{~km}^{2}$ in size witnessed minimum area loss of $3.0 \pm 1.5 \mathrm{~km}^{2}(4.6 \pm 2.2$ or $0.1 \pm$ $0.1 \% \mathrm{a}^{-1}$ ) mainly due to lowest mean elevation (i.e. comparatively lower terminus elevation) and highest percentage of clean-ice area (89.35\%) in 2016 (Table 4; Fig. 11a). Change in small glaciers is higher than valley glaciers, not ignoring the fact that earlier image database had snowdrift accumulation in the higher region. In absolute term, large glaciers lost more area than small glaciers (Fig. 11b).
Relative area change according to morphological categories is interpreted in Table 5.

Glaciers with southward aspect (including southeast, south and southwest) have decreased by $21.2 \pm 2.2$ or 0.5 $\pm 0.1 \% \mathrm{a}^{-1}$, while glaciers with northward aspect (including north, northeast and northwest) have receded by $13.7 \pm 1.8$ or $0.3 \pm 0.01 \% \mathrm{a}^{-1}$ between 1971 and 2016 (Fig. 11d). In addition, glaciers with the west and east aspect have lost their area by $15.1 \pm 1.9$ or $0.3 \pm 0.01 \% \mathrm{a}^{-1}$ (Fig. $11 \mathrm{~d}$ ). Area change rate is almost twice the rate for glacier above 5400 $\mathrm{m}$ a.s.l. as compared with those below $5400 \mathrm{~m}$ a.s.l. (Table 6; Fig. 11e). The glaciers above $500 \mathrm{~m}$ elevation range receded at a lower rate as compared with others (Fig. 11f).

\section{Climatic trends}

In the absence of availability of long-term climatic data within the JCW, we analyzed available grided temperature data based on US National Center for Environmental Prediction/National Center for Atmospheric Research (NCEP/NCAR) reanalysis data between 1948 and 2017 (see Kalnay and others, 1996). Temperature $\left({ }^{\circ} \mathrm{C}\right)$ trend was analyzed for the grid $\left(32.5^{\circ} \mathrm{N}\right.$ and $\left.77.5^{\circ} \mathrm{E}\right)$ located within the JCW based on Mann-Kendall method (Bhambri and others, 2011; Negi and others, 2013; Chand and Sharma, 2015) (Supplementary Table S3). The mean annual temperature (MAT) showed an insignificant increasing trend $\left(0.0078^{\circ} \mathrm{C}\right.$ $\mathrm{a}^{-1}$ ) from 1948 to 2017 (Fig. 12), but the MAT increases significantly between 1997 and 2016. Winter (December, January, February: DJF) mean temperature increased significantly by $\sim 1.3^{\circ} \mathrm{C}$ for the selected grid while summer (March, April, May: MAM) mean temperature decreased by $\sim 0.2{ }^{\circ} \mathrm{C}$ between 1948 and 2017 (Supplementary Table S3).

\section{DISCUSSION}

\section{Comparison with RGIv6.0/GAMDAM and ICIMOD}

For comparison and cross-check, vector shapefile derived from: (i) glacier outlines of RGlv6.0/GAMDAM (2000 \pm 3 ) and (ii) ICIMOD $(2008 \pm 3)$ were overlaid with the outlines derived from Sentinel 2A (2016). A comparison of our results with those published by RGIv6.0 using the data from GAMDAM inventory (Nuimura and others, 2015) indicated that glacier area in the JCW was overestimated $\left(\sim 6.7 \mathrm{~km}^{2}\right.$ or $\left.\sim 4 \%\right)$, while glacier number was underestimated ( 11 or $\sim 8 \%$ ) by RGlv6.0/GAMDAM (Supplementary Table S4). Ironically, in the revised version of GlobGlacier inventory (RGI v6), the number of glaciers in the JCW had shown a significant decrease $(\sim 27.92 \%)$ from its earlier version (RGI v4). The ICIMOD glacier inventory contains 145 glaciers covering an area of $\sim 177.3 \mathrm{~km}^{2}$ with similar minimum size $\left(0.02 \mathrm{~km}^{2}\right)$. Interestingly, in the present analysis, we obtained more glaciers (8 or $\sim 6 \%$ ) as well as a larger glacierized area $\left(\sim 8.26 \mathrm{~km}^{2}\right.$ or $\left.\sim 5 \%\right)$ a decade later in 2016 (Supplementary Table S4). We suggest that this variation is attributed to (i) misinterpretation of debris-free and debris-covered glaciers; (ii) temporal differences in terms of acquired images and mapping period; (iii) differences in classification of glacier area/boundary; and (iv) adjacent ice masses may have been clumped as a single entity (Supplementary Figure S3). In addition, Birajdar and others (2014) have generated a glacier inventory of Bhaga basin 

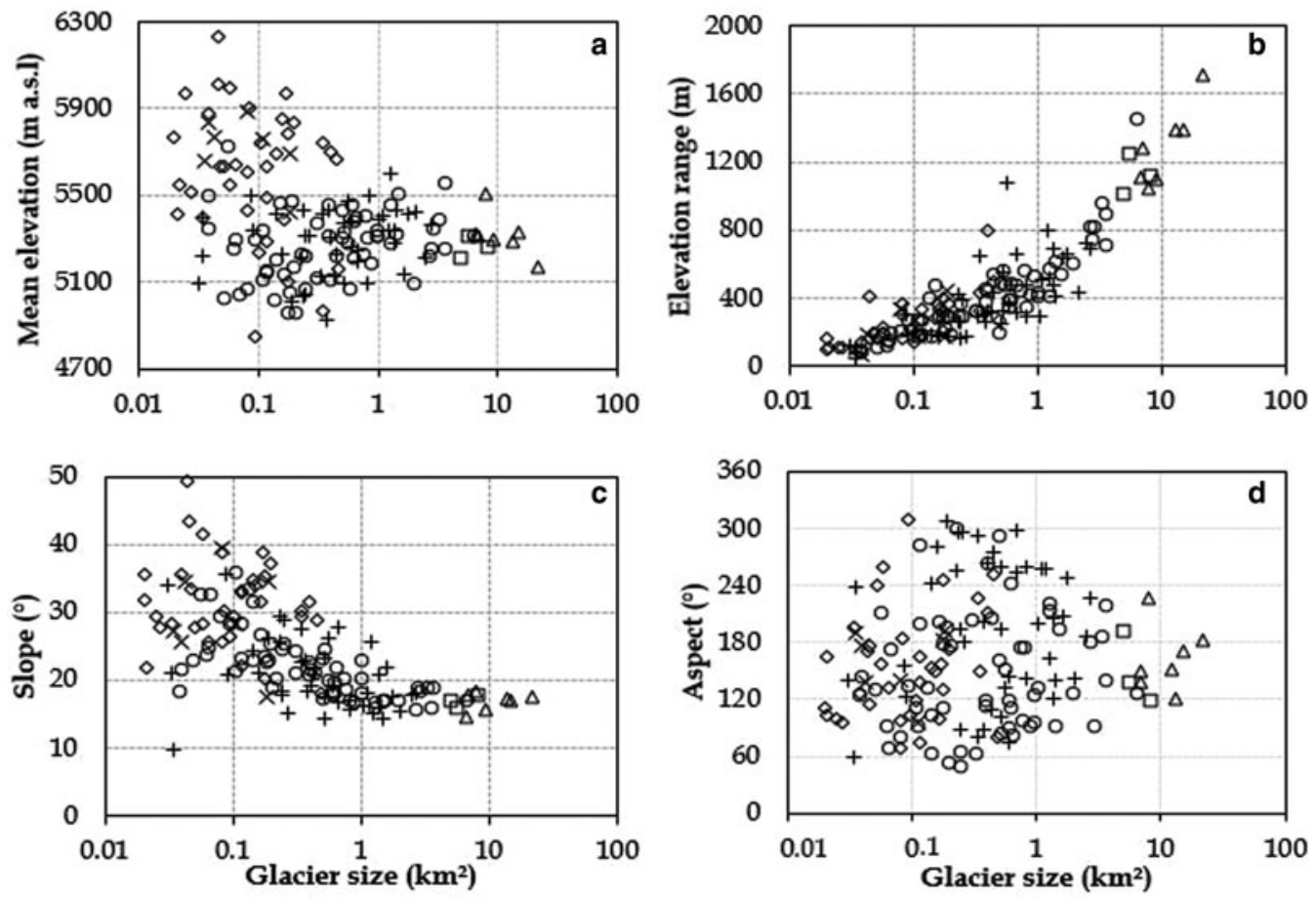

Fig. 7. Scatter plots of (a) glacier size vs mean elevation, (b) glacier size vs elevation range, (c) glacier size vs slope and (d) glacier size vs aspect. Triangle, rhombus, circle, plus, cross and square represent valley, plateau, simple (mountain) basin, cirque, hanging and compound (mountain) basin glacier, respectively. Glacier area and inventory data derived from Sentinel 2A (1 November 2016) and ASTER GDEM v2.

for 2011 using Indian remote-sensing linear imaging selfscanning sensor (LISS III) data and the ASTER GDEM at 1:50 000 scale which is not freely available (Supplementary Table S4). The Geological Survey of India (GSI) also attempted a glacier inventory based on the Sol topographic maps, aerial photographs and satellite images for the Indian Himalaya (Raina and Srivastava, 2008).

\section{Comparison of area change within Chenab basin}

The present study indicates that glacier recession rate in the JCW $\left(0.17 \pm 0.01 \% \mathrm{a}^{-1}\right)$ from 1971 to 2016 is less than reported for Chenab basin. Our study shows an apparently lower retreat rate compared with the analyses using Sol maps derived glacier boundary (Kulkarni and Alex, 2003; Kulkarni and others, 2007, 2010; Sharma and others, 2016;
Brahmbhatt and others, 2017) (Supplementary Table S5). For instance, glaciers in the Bhaga basin retreated at $\sim 0.8 \% \mathrm{a}^{-1}$, in Chenab at $\sim 0.5 \% \mathrm{a}^{-1}$, in Miyar at $\sim 0.2 \%$ $\mathrm{a}^{-1}$, in Warwan at $\sim 0.5 \% \mathrm{a}^{-1}$ between 1962 and 2001/04 (Kulkarni and others, 2007; Kulkarni, 2010) (Supplementary Table S5). Kulkarni and others (2006) showed that Samudra Tapu glacier (source of Chandra River) retreated by $11 \%$ or $\sim 0.3 \% \mathrm{a}^{-1}$ between 1962 (Sol maps) and 2000 (LISS III images). In Warwan-Bhut region of Chenab basin, Brahmbhatt and others (2017) reported area loss of $11 \%$ $\left(\sim 0.3 \% \mathrm{a}^{-1}\right)$ based on Sol maps (1962) and LISS III (2001) images. The higher rate of glacier retreat could be a result of an overestimation of glacier cover in the Sol maps as reported by previous studies (Bhambri and others, 2011; Chand and Sharma, 2015). Negi and others (2013) noted higher retreat rate $\left(\sim 0.4 \pm 0.1 \% \mathrm{a}^{-1}\right)$ for small Baralacha
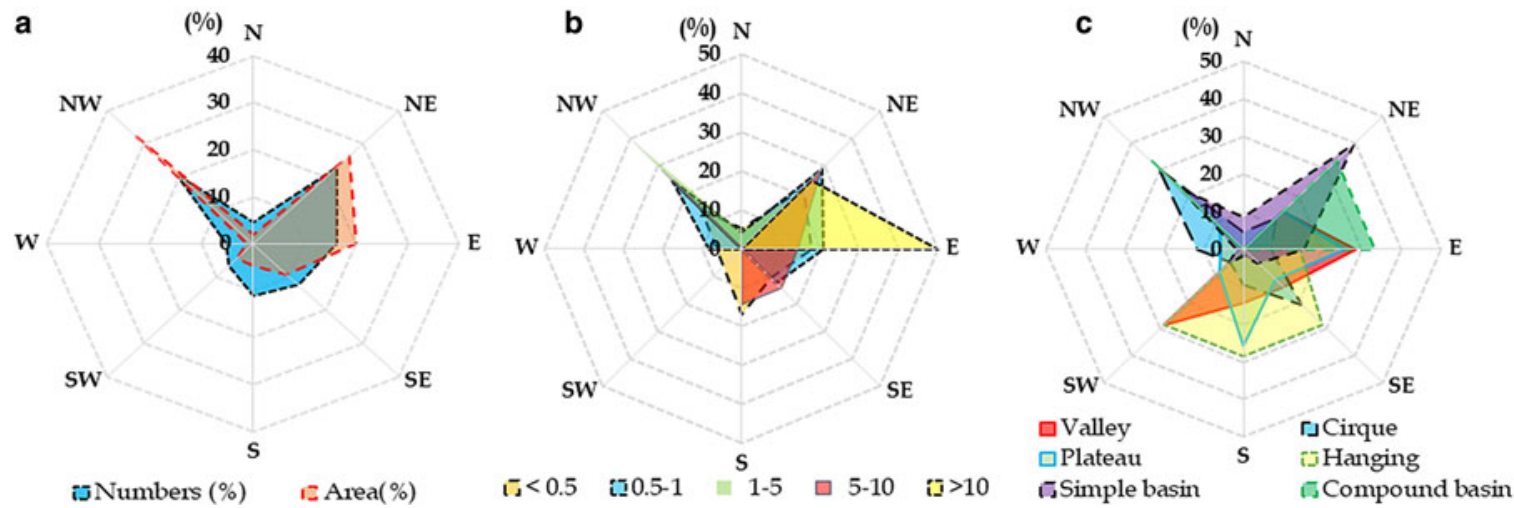

Fig. 8. Distribution of glaciers according to aspect in the Jankar Chhu Watershed. (a) Number of the glaciers and glaciated area (\%). (b) Number of glaciers $(\%)$ in relation to the size class. (c) Number of glaciers (\%) in relation to morphological types. Glacier area and elevation data derived from Sentinel 2A (1 November 2016) and ASTER GDEM v2. 


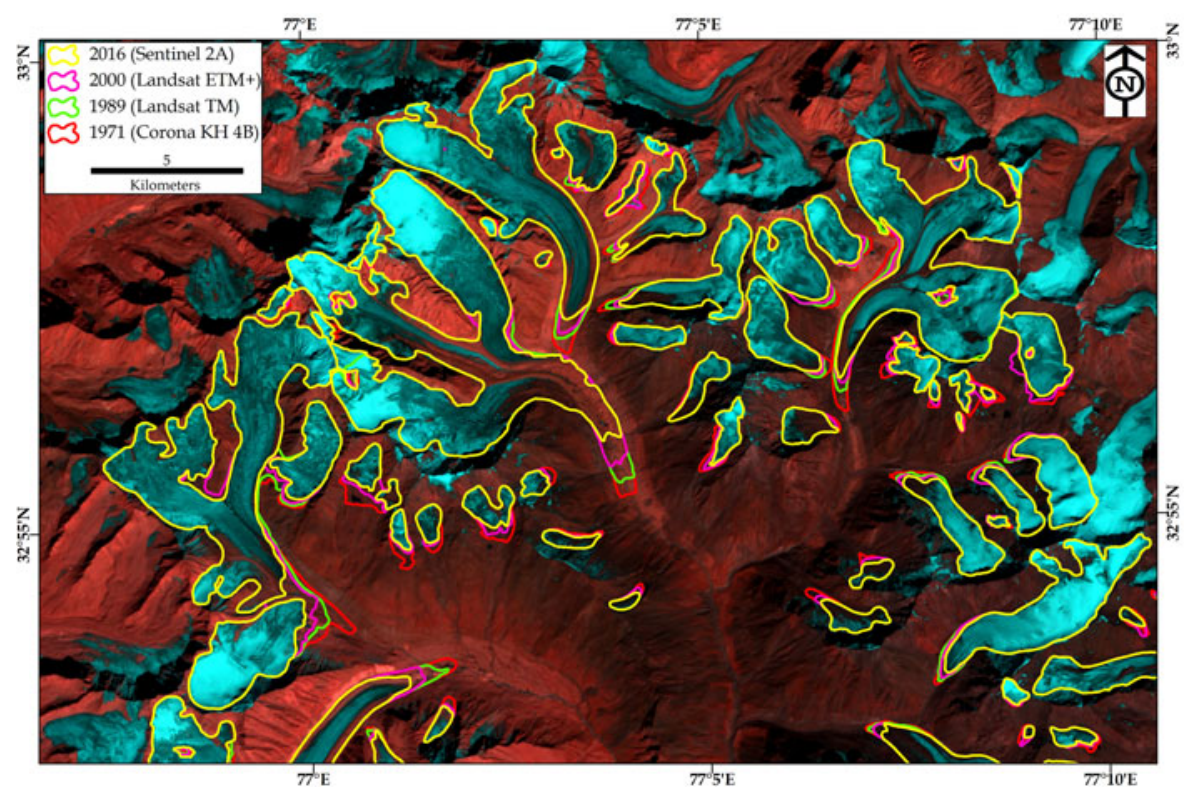

Fig. 9. An example of glacier changes between 1971 and 2016 in the Jankar Chhu Watershed, Lahaul Himalaya (see Fig. 1b for location). Sentinel 2A (12-4-3 bands) image is used as background.

glacier in Bhaga basin between 1971 and 2010 using Corona, Landsat and LISS IV images (Supplementary Table S5).

Our analysis of glacier area change for the JCW also confirms published trends as reported by Pandey and Venkataraman (2013) and Birajdar and others (2014) (Supplementary Table S5). Birajdar and others (2014) observed retreat rate of $0.16 \pm 0.1 \% \mathrm{a}^{-1}$ in Bhaga basin from 2001 to 2011 which is similar to our result $(0.17 \pm$ $\left.0.01 \% \mathrm{a}^{-1}\right)$. In line with our assumption and data, Pandey and Venkataraman (2013) also reported similar retreat rate of $\sim 0.1 \% \mathrm{a}^{-1}$ for the 15 selected glaciers in Chandrabhaga basin (1980-2010), using exclusively remotely sensed datasets. In adjacent Miyar basin, Patel and others (2018) observed similar retreat rate $\left(\sim 0.16 \% \mathrm{a}^{-1}\right)$ (Supplementary Table S5). Based on satellite imagery, Garg and others (2017a) reported lower retreat rate for Sakchum $(\sim 0.15 \%$ $\left.\mathrm{a}^{-1}\right)$, Chhota Shigri $\left(\sim 0.06 \% \mathrm{a}^{-1}\right)$ and Bara Shigri $(\sim 0.04 \%$ $\mathrm{a}^{-1}$ ) glaciers in upper Chenab basin between 1993 and 2014 (Supplementary Table S5).

\section{Comparison of area change with other Himalayan basins}

Glacier area change studies carried out across the Himalaya have been given in Supplementary Table S5. In Western Himalaya (1962-2001), glaciers retreated at higher rate than the present study (Kulkarni and others, 2007; Kulkarni, 2010; Schmidt and Nüsser, 2012; Chudley and others, 2017). Based on Corona and Landsat images, Chand and Sharma (2015) recorded much lower retreat rate $(\sim 0.1 \pm$ $\left.0.1 \% \mathrm{a}^{-1}\right)$ in Ravi basin of Himachal Himalaya. In Garhwal Himalaya, Bhambri and others (2011) reported similar retreat rate to the present one (Supplementary Table S5). Bolch and others (2008) stated glacier area loss by $5.2 \%$ $\left(\sim 0.12 \% \mathrm{a}^{-1}\right)$ in the Kumbhu Himalaya. For Bhutan Himalaya, Bajracharya and others (2015) showed higher retreat rate between 1980 and 2010 derived using Landsat images (Supplementary Table S5).

\section{Potential reason for debris cover increase}

Several studies have indicated that the debris-covered area has increased on glacier surface over time, and such glaciers show a lower rate of recession as compared with clean glaciers in the Himalaya (Bolch and others, 2008; Bhambri and others, 2011; Kamp and others, 2011; Chand and Sharma, 2015). The present study also confirms that the number as well as area of debris-covered glaciers has increased by 15 and $7.2 \pm 3.8 \mathrm{~km}^{2}\left(\sim 0.16 \pm 0.1 \mathrm{~km}^{2} \mathrm{a}^{-1}\right)$, respectively, between 1971 and 2016, probably due to the melting of clean-ice surface resulting in the exposure of debris-cover surface. Different spatial resolution (Corona: $2 \mathrm{~m}$; Sentinel 2A: $10 \mathrm{~m}$ ) as well as time gap of image acquisition (Corona: 28 September 1971; Sentinel 2A: 1 November 2016; 33 day gap) may lead to overestimation of debris-covered ice area in the JCW, not ignoring the role of local weather regime in such complex terrain. In Bhutan Himalaya, Nagai and others (2013) observed a significant correlation between the surface area of southwest facing potential debris supply (PDS) slopes and debris-covered area with a maximum contribution of debris mantle from the southwest facing PDS slopes. To investigate whether this relation of debris cover exists in the JCW, we demarcated the distribution of PDS slope for the glaciers which have more than $10 \%$ of debris-covered area to the total area (Supplementary Figure S4). It is found that $50 \%$ of PDS slope for these glaciers $(>10 \%$ of debris-covered area) is in the south (including south, southeast and southwest) facing. A similar pattern is also reported in the Ravi basin, northwestern Himalaya (Chand and Sharma, 2015). Thus, the suggested explanation of debris supply from PDS slope surrounding the glaciers might apply for the JCW too. Several studies have emphasized the significance of supraglacial debris cover on the glacier dynamics in response to climate change whereby modifying surface ablation rates and spatial patterns of mass loss (Benn and Lehmkuhl, 2000; Scherler and others, 2011a; Dobhal and others, 2013; Pratap and others, 2015). In addition, experimental and short-period (ablation season) studies suggest that thick 
debris cover reduces ablation, whereas thin debris layer increases ice melt underneath (Pratap and others, 2015). Debris-covered ice in the JCW is mainly confined to large valley glaciers where terminus fluctuation may have been affected by the supraglacial debris cover.

\section{Influence of non-climatic factors on glacier fluctuations}

Since 2000, the rate of recession has increased in the JCW of Lahaul Himalaya. A similar trend in glacier recession has been reported in the Gharwal Himalaya (Bhambri and others, 2011) and in the Kumbhu Himalaya (Bolch and others, 2008). The number of glaciers increased by four in the JCW between 1971 and 2016, which we attribute to glacier fragmentation. A similar trend has been reported in the other basins of Western Himalaya (Kulkarni and others, 2007; Chand and Sharma, 2015) and Central Himalaya (Bhambri and others, 2011).

In the JCW, glaciers $<1 \mathrm{~km}^{2}$ in size have lost $14.3 \pm 2.1 \%$ $\left(\sim 0.3 \pm 0.1 \% \mathrm{a}^{-1}\right)$ of area from 1971 to 2016 , whereas in similar basin (e.g. Chenab) Kulkarni and others (2007) found that glaciers $<1 \mathrm{~km}^{2}$ in size lost 38\% $\left(\sim 1 \% \mathrm{a}^{-1}\right)$ of area between 1962 (Sol maps) and 2001/04. We observed a negative correlation $(r=-0.4)$ between glacier size and relative surface area change while the absolute area change showed a significant positive correlation $(r=0.7)$ with glacier size by simple linear regression (Figs 11a, b). It is difficult to ascertain the reason whether the elevation or little accumulation area is a factor for the rapid recession of small glaciers in the JCW. Our results show that small glaciers receded at a faster rate than large glaciers in the JCW. Many studies have already highlighted that smaller glaciers are characterized by a higher rate of decrease in area as compared with larger glaciers (Bolch and others, 2010; Bhambri and others, 2011; Schmidt and Nüsser, 2012; Negi and others, 2013; Chand and Sharma, 2015).

The north facing (including north, northwest and northeast) glaciers receded less than the south (including south, southwest and southeast) facing ones in the JCW (Fig. 11d). It may be due to less radiation received by the northern slopes than the south facing Himalayan slopes (Scherler and others, 2011b). Thus the north facing glaciers are likely to have responded slowly than the south facing ones in the JCW. Whether such a response is to be related to reduce precipitation is not readily recognized.

Glaciers with lower mean elevation receded less than the glacier in higher elevation. We found very low positive correlation $(r=0.2)$ between mean elevation ( $\mathrm{m}$ a.s.l.) and glacier area change $(\%)$ while elevation range $(\mathrm{m})$ exhibited significant negative correlation $(r=-0.5)$ (Figs 11e, f), indicating that elevation range is more influential factor for glacier surface area loss as compared with mean elevation in the JCW. Glacier morphology (e.g. shape, size and hypsometry), steep slope and small accumulation area may accelerate the retreat rate of glaciers on higher elevations in such region (Salerno and others, 2017; Garg and others, 2017b), not ignoring the fact that large valley glaciers have longer response times.

\section{Potential climatic controls on glacier fluctuations}

The analysis of NCEP/NCAR data shows that MAT within the JCW region increased by $\sim 0.5^{\circ} \mathrm{C}$ between 1948 and 2017 . 

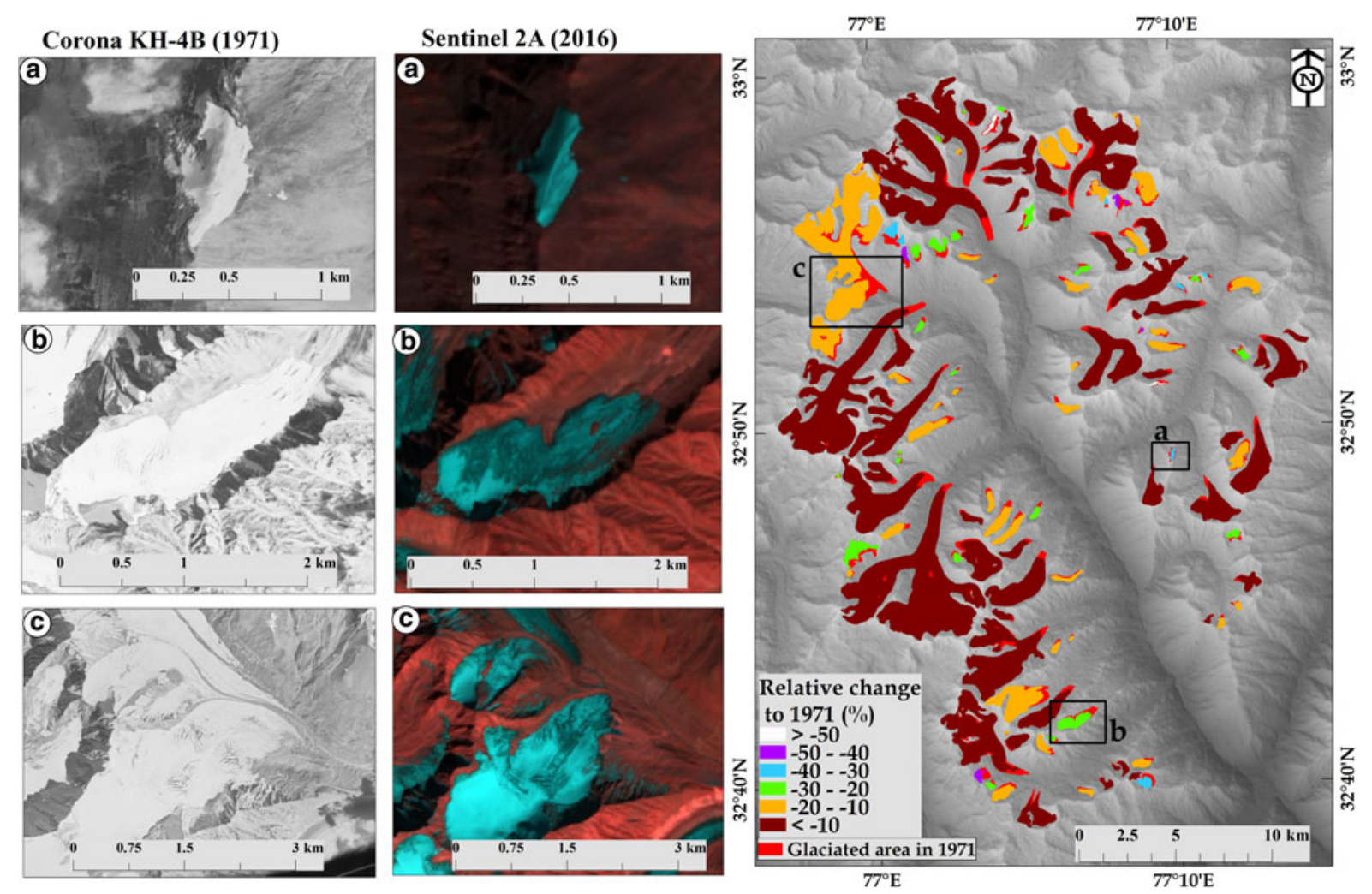

Fig. 10. Map of relative glacier area change (\%) between 1971 and 2016 in the Jankar Chhu Watershed (right panel). Satellite images of three sets of glaciers showing surface area change between 1971 (Corona) and 2016 (Sentinel 2A) (left panel).

Negi and others (2013) reported that MAT increased by $\sim 2.2^{\circ}$ $\mathrm{C}\left(\sim 0.07^{\circ} \mathrm{C} \mathrm{a}^{-1}\right)$ and winter snowfall decreased by $\sim 242.1$ $\mathrm{cm}\left(8.3 \mathrm{~cm} \mathrm{a}^{-1}\right)$ for Patsio between 1983 and 2011. Shehmani and others (2015) noted decreasing mean seasonal snowfall $\left(0.07 \mathrm{~cm} \mathrm{a}^{-1}\right)$ in Bhaga basin during 2001-12. Shekhar and others (2010) have reported an increase of $2.8^{\circ}$ $C$ in annual maximum temperature ( $T_{\text {MAX }}$ ) between 1984/85 and 2007/08 in the Western Himalaya; while minimum temperature $\left(T_{\mathrm{MIN}}\right)$ increased by $\sim 1^{\circ} \mathrm{C}$ during the similar period. Dash and others (2007) also mentioned that $T_{\text {MIN }}$ decreased by $1.9^{\circ} \mathrm{C}$ over the Western Himalaya during 1955-72 and increasing trend in last decades. Bhutiyani and others (2010) had reported the annual warming rate of $1.6^{\circ} \mathrm{C}$ over the last century with a significant increase of $\sim 3.2^{\circ} \mathrm{C}$ in winter average $T_{\text {MAX }}$. In addition, summer cooling has been reported in some part of the Western Himalaya and upper Indus basin during the last two decades of the 20th century (Yadav and others, 2004; Bhutiyani and others, 2007; Rajbhandari and others, 2014). Our analysis of NCEP/NCAR reanalysis data also suggests strong warming trends in winter and weaker cooling in summer, suggesting a lower annual variability which is one of the regional causes of glacial waning. Bhutiyani and others (2010) also described significant decreasing trends in the monsoon precipitation during the period 1866-2006. Shekhar and others (2010) reported a decrease in total seasonal snowfall of $\sim 280 \mathrm{~cm}$ over the entire Western Himalaya and $\sim 440 \mathrm{~cm}$ in the Greater Himalaya range between 1988/89 and 2007/08 which appears to be factually incorrect and extraordinary inflated value. They have taken only two time periods of data and not of continuous years. However, Shehmani and others (2015) support our field observation and reality. The field region is being visited twice a year, pre- and post-monsoon since 2003. Snow and glacier conditions (e.g. available snowfields, avalanche cones and amount of meltwaters) are recorded accordingly on either of the field visits.

Table 4. Area loss according to glacier size class from 1971 to 2016 in the Jankar Chhu Watershed

\begin{tabular}{|c|c|c|c|c|c|c|c|}
\hline \multirow[b]{2}{*}{ Glacier size $\left(\mathrm{km}^{2}\right)$} & \multicolumn{2}{|c|}{ No of glaciers } & \multicolumn{2}{|c|}{ Total area $\left(\mathrm{km}^{2}\right)$} & \multirow{2}{*}{$\begin{array}{l}\text { Absolute area } \\
\text { change }\left(\mathrm{km}^{2}\right)\end{array}$} & \multirow{2}{*}{$\begin{array}{l}\text { Relative area } \\
\text { change }(\%)\end{array}$} & \multirow{2}{*}{$\begin{array}{c}\text { Relative area change } \\
\text { rate }\left(\% \mathrm{a}^{-1}\right)\end{array}$} \\
\hline & 1971 & 2016 & 1971 & 2016 & & & \\
\hline$<0.5$ & 66 & 75 & $13.4 \pm 0.2$ & $12.7 \pm 0.2$ & $0.7 \pm 0.3$ & $5.3 \pm 2.2$ & $0.1 \pm 0.05$ \\
\hline $0.5-1$ & 25 & 22 & $17.3 \pm 0.2$ & $13.6 \pm 0.3$ & $3.7 \pm 0.3$ & $21.3 \pm 2.0$ & $0.5 \pm 0.04$ \\
\hline $1-5$ & 25 & 24 & $49.6 \pm 0.6$ & $44.8 \pm 0.9$ & $4.8 \pm 1.0$ & $9.7 \pm 2.1$ & $0.2 \pm 0.05$ \\
\hline $5-10$ & 7 & 6 & $49.3 \pm 0.6$ & $46.9 \pm 0.9$ & $2.4 \pm 1.1$ & $4.9 \pm 2.2$ & $0.1 \pm 0.05$ \\
\hline$<5$ & 116 & 121 & $80.3 \pm 0.9$ & $71.1 \pm 1.4$ & $9.2 \pm 1.7$ & $11.5 \pm 2.1$ & $0.3 \pm 0.05$ \\
\hline$>5$ & 11 & 10 & $115.7 \pm 1.3$ & $110.3 \pm 2.2$ & $5.4 \pm 2.6$ & $4.7 \pm 2.2$ & $0.1 \pm 0.05$ \\
\hline Total & 127 & 131 & $196.0 \pm 2.3$ & $181.4 \pm 3.6$ & $14.6 \pm 4.3$ & $7.5 \pm 2.2$ & $0.2 \pm 0.05$ \\
\hline
\end{tabular}



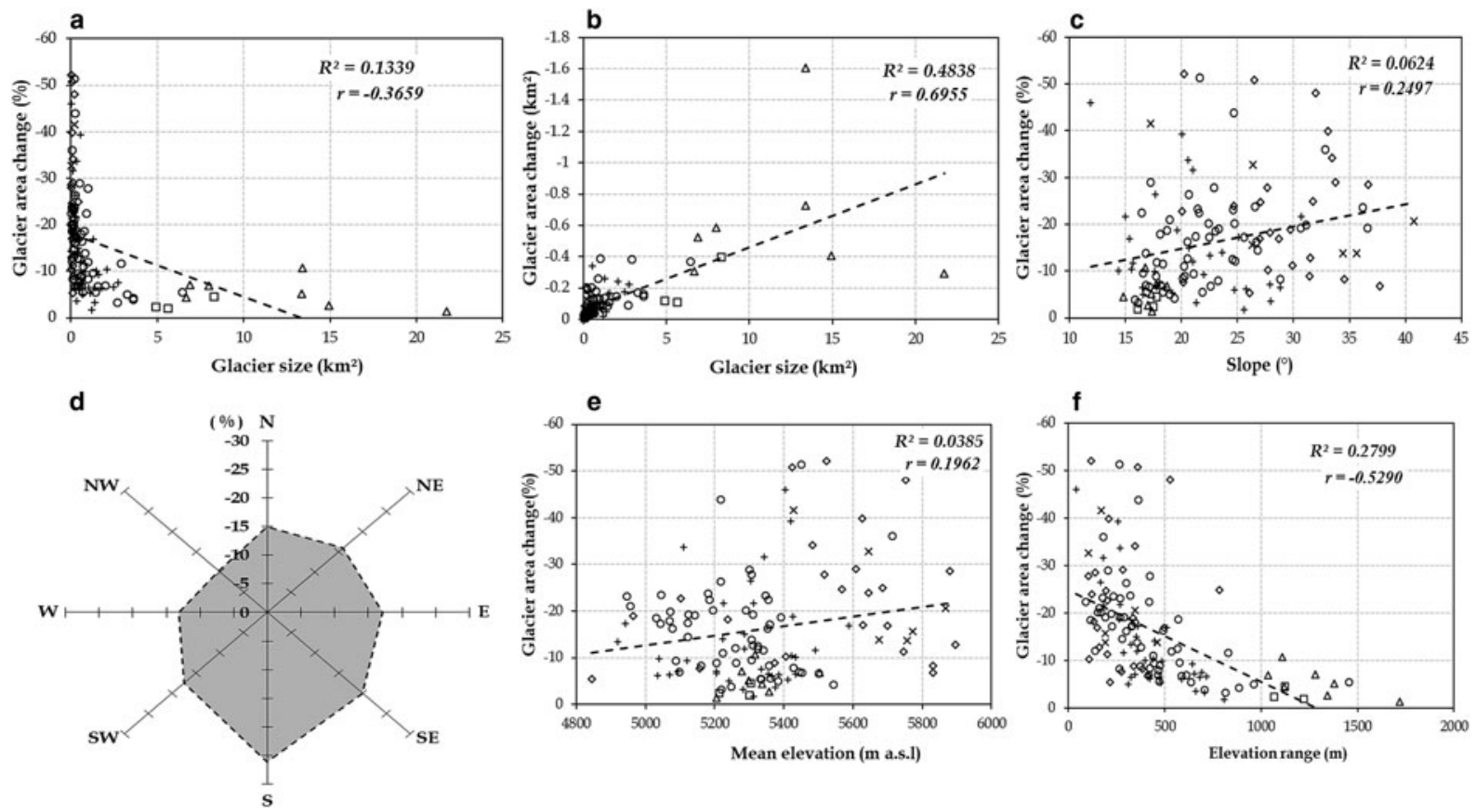

Fig. 11. Scatter plots of (a) glacier size $\left(\mathrm{km}^{2}\right)$ vs glacier area change (\%), (b) glacier size $\left(\mathrm{km}^{2}\right)$ vs glacier area change $\left(\mathrm{km}^{2}\right)$, (c) mean slope vs glacier area change $(\%),(\mathrm{d})$ aspect vs glacier area change $(\%),(\mathrm{e})$ mean elevation vs glacier area change $(\%)$ and (f) elevation range vs glacier area change (\%) for 127 analyzed glaciers. Triangle, rhombus, circle, plus, cross and square represent valley, plateau, simple (mountain) basin, cirque, hanging and compound (mountain) basin glacier, respectively.

Table 5. Area loss according to glacier morphological type between 1971 and 2016 in the Jankar Chhu Watershed

\begin{tabular}{|c|c|c|c|c|c|c|c|}
\hline \multirow[b]{2}{*}{ Glacier type } & \multicolumn{2}{|r|}{1971} & \multirow{2}{*}{$\frac{1971}{\text { Total area }\left(\mathrm{km}^{2}\right)}$} & \multirow{2}{*}{$\frac{2016}{\text { Total area }\left(\mathrm{km}^{2}\right)}$} & \multirow{2}{*}{$\begin{array}{l}\text { Absolute area } \\
\text { change }\left(\mathrm{km}^{2}\right)\end{array}$} & \multirow{2}{*}{$\begin{array}{c}\text { Relative area } \\
\text { change }(\%)\end{array}$} & \multirow{2}{*}{$\begin{array}{c}\text { Relative area change } \\
\text { rate }\left(\% \mathrm{a}^{-1}\right)\end{array}$} \\
\hline & No & Mean size $\left(\mathrm{km}^{2}\right)$ & & & & & \\
\hline Valley & 7 & 12.8 & $89.4 \pm 1.0$ & $85.0 \pm 1.7$ & $4.4 \pm 2.0$ & $4.9 \pm 2.2$ & $0.1 \pm 0.01$ \\
\hline Cirque & 34 & 0.9 & $31.6 \pm 0.4$ & $28.4 \pm 0.6$ & $3.2 \pm 0.7$ & $10.1 \pm 2.2$ & $0.2 \pm 0.02$ \\
\hline Plateau & 24 & 0.2 & $4.6 \pm 0.1$ & $3.6 \pm 0.1$ & $1.0 \pm 0.1$ & $21.7 \pm 2.1$ & $0.5 \pm 0.05$ \\
\hline Hanging & 6 & 0.1 & $0.9 \pm 0.0$ & $0.7 \pm 0.01$ & $0.2 \pm 0.1$ & $22.2 \pm 11.1$ & $0.5 \pm 0.25$ \\
\hline Simple basin & 53 & 0.9 & $50.1 \pm 0.6$ & $44.9 \pm 0.9$ & $5.2 \pm 1.1$ & $10.4 \pm 2.2$ & $0.2 \pm 0.05$ \\
\hline Compound basin & 3 & 6.5 & $19.5 \pm 0.2$ & $18.9 \pm 0.4$ & $0.6 \pm 0.5$ & $3.1 \pm 2.6$ & $0.1 \pm 0.06$ \\
\hline Total & 127 & & $196.0 \pm 2.3$ & $181.4 \pm 3.6$ & $14.6 \pm 4.3$ & $7.5 \pm 2.2$ & $0.2 \pm 0.05$ \\
\hline
\end{tabular}

Based on climatic trends identified from NCEP/NCAR data and existing studies, it might be argued that loss of glacier surface area in the JCW between the 1970s and 2016 reflects the combined influence of rising temperature and declining precipitation. Since 1950-1990, MAT showed negative trend, while in recent decades (1990-2017), MAT increased at a significant rate (Fig. 12). In the present study, we had higher area loss rate $\left(\sim 0.2 \pm 0.02 \% \mathrm{a}^{-1}\right)$ in recent decades (2000-16) as compared with previous decades $(\sim 0.1 \pm$ $0.01 \% \mathrm{a}^{-1} ;$ 1971-2000). Higher deglaciation in recent

Table 6. Glacier area loss according to elevation zones between 1971 and 2016 in the Jankar Chhu Watershed

\begin{tabular}{|c|c|c|c|c|c|c|}
\hline \multirow[b]{2}{*}{ Elevation (m a.s.I.) } & \multirow{2}{*}{$\begin{array}{l}\text { Number } \\
(1971)\end{array}$} & \multicolumn{2}{|c|}{ Total area $\left(\mathrm{km}^{2}\right)$} & \multirow{2}{*}{$\begin{array}{l}\text { Absolute area } \\
\text { change }\left(\mathrm{km}^{2}\right)\end{array}$} & \multirow{2}{*}{$\begin{array}{l}\text { Relative area } \\
\text { change }(\%)\end{array}$} & \multirow{2}{*}{$\begin{array}{c}\text { Relative area change } \\
\text { rate }\left(\% \mathrm{a}^{-1}\right)\end{array}$} \\
\hline & & 1971 & 2016 & & & \\
\hline $4800-5000$ & 6 & $1.7 \pm 0.02$ & $1.4 \pm 0.03$ & $0.3 \pm 0.04$ & $17.7 \pm 2.3$ & $0.4 \pm 0.1$ \\
\hline 5000-5200 & 26 & $34.4 \pm 0.4$ & $32.5 \pm 0.7$ & $1.9 \pm 0.8$ & $5.5 \pm 2.3$ & $0.1 \pm 0.1$ \\
\hline 5200-5400 & 53 & $128 \pm 1.5$ & $119.3 \pm 2.4$ & $8.7 \pm 2.8$ & $6.8 \pm 2.2$ & $0.2 \pm 0.1$ \\
\hline $5400-5600$ & 24 & $28.8 \pm 0.3$ & $25.7 \pm 0.5$ & $3.1 \pm 0.6$ & $10.8 \pm 2.1$ & $0.2 \pm 0.1$ \\
\hline 5800-6000 & 5 & $0.6 \pm 0.01$ & $0.6 \pm 0.01$ & $0.1 \pm 0.01$ & $11.1 \pm 1.6$ & $0.3 \pm 0.04$ \\
\hline$<5400$ & 85 & $164.1 \pm 1.9$ & $153.2 \pm 3.1$ & $11 \pm 0.6$ & $6.64 \pm 0.4$ & $0.1 \pm 0.01$ \\
\hline$>5400$ & 42 & $31.9 \pm 0.4$ & $28.2 \pm 0.6$ & $3.7 \pm 0.7$ & $11.60 \pm 2.1$ & $0.3 \pm 0.1$ \\
\hline Total & 127 & $196.0 \pm 2.3$ & $181.4 \pm 3.6$ & $14.6 \pm 4.3$ & $7.45 \pm 2.2$ & $0.2 \pm 0.1$ \\
\hline
\end{tabular}




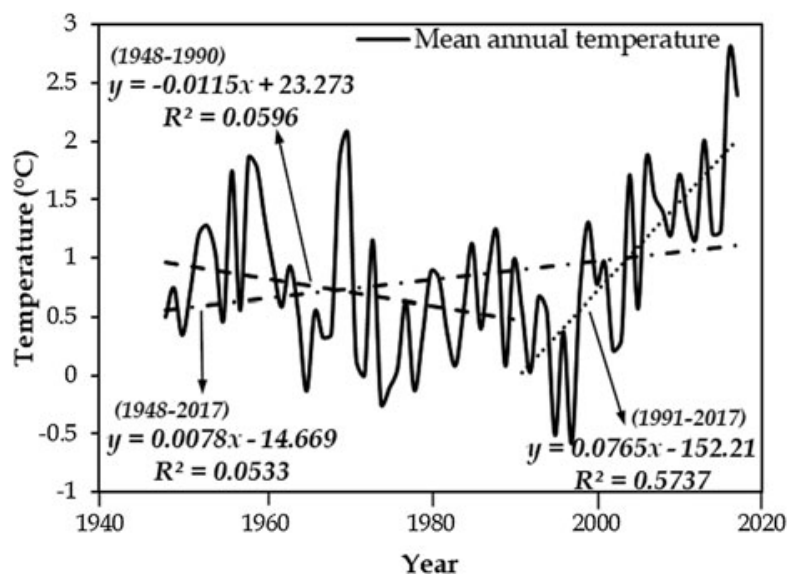

Fig. 12. Trends in mean annual temperature $\left({ }^{\circ} \mathrm{C}\right)$ between 1948 and 2017 for the part of Lahaul Himalaya $\left(32.5^{\circ} \mathrm{N}\right.$ and $77.5^{\circ} \mathrm{E}$ grid within the JCW) based on US National Center for Environmental Prediction/ National Center for Atmospheric Research (NCEP/NCAR) reanalysis I datasets at $2.5^{\circ} \times 2.5^{\circ}$ spatial resolution. Data source: NCEP reanalysis data provided by the NOAA/OAR/ESRL PSD, Boulder, Colorado, USA, and downloaded from their website (https://www. esrl.noaa.gov/psd/).

decades may be attributed to increasing trend in MAT as well as decreasing trend in precipitation as reported elsewhere. The availability of long-term instrumental climatic records and field-based measurements (e.g. mass balance, debris cover thickness) within the watershed will provide a valuable database and further improve knowledge of glacier change and its interaction/response to ongoing changes in climatic parameters in the JCW of Lahaul Himalaya.

\section{CONCLUSION}

This study provides a comprehensive multi-temporal glacier fluctuations record for the JCW, Chandrabhaga basin, Lahaul Himalaya between 1971 and 2016. Glacier area decreased by $14.7 \pm 4.3 \mathrm{~km}^{2}\left(0.3 \pm 0.1 \mathrm{~km}^{2} \mathrm{a}^{-1}\right)$ from 1971 to 2016. Glaciers lost less area $\left(0.1 \pm 0.1 \% \mathrm{a}^{-1}\right)$ during 1971-2000 than 2000-2016 $\left(0.2 \pm 0.2 \% \mathrm{a}^{-1}\right)$. Debris cover increased by $7.2 \pm 0.4 \mathrm{~km}^{2}\left(\sim 0.2 \pm 0.01 \mathrm{~km}^{2} \mathrm{a}^{-1}\right)$ between 1971 and 2016. Glacier recession rate is comparatively lower in the JCW than other basins of Western Himalaya (e. g. Chenab, Beas, Miyar, Parbati, Tirungkhad and Baspa). Smaller glaciers $\left(<1 \mathrm{~km}^{2}\right)$ lost $14.3 \pm 2.1 \%$ of ice, while glaciers $>10 \mathrm{~km}^{2}$ in size lost $4.6 \pm 2.2 \%$, which is a common trend between glacier size and average shrinkage rate. Glaciers with south aspect shrank at a faster rate than glacier with other aspects. The influence of topographical factors on glacier change rates needs to be studied with respect to the response of the glacier to ongoing changes in climatic parameters.

\section{SUPPLEMENTARY MATERIAL}

The supplementary material for this article can be found at https://doi.org/10.1017/jog.2018.77.

\section{ACKNOWLEDGEMENTS}

S. Das is thankful to the University Grant Commission, New Delhi (3090/ (NET-DEC.2014) for financial support during field observations. We also thank USGS for providing
Sentinel 2A, Landsat and Corona data at no cost. We acknowledge the DST-CCP/SPLICE (IUCCCC) for supporting field comparing and laboratory facilities. Hester Jiskoot and Neil Glasser are thanked for constructive comments of the paper. We also thank two anonymous referees for their insightful suggestions, which considerably improved the earlier version of the manuscript.

\section{REFERENCES}

Bajracharya B and Shrestha SR (eds) (2011) The status of glaciers in the Hindu Kush-Himalayan region. Kathmandu: International Centre for Integrated Mountain Development.

Bajracharya SR, Maharjan SB and Shrestha F (2014) The status and decadal change of glaciers in Bhutan from the 1980s to 2010 based on satellite data. Ann. Glaciol., 55(66), 159-166

Bajracharya SR and 6 others (2015) The glaciers of The Hindu Kush Himalayas: current status and observed changes from the 1980s to 2010. Int. J. Water Resour. Dev., 31(2), 161-173

Bashir F, Zeng X, Gupta H and Hazenberg P (2017) A hydrometeorological perspective on the Karakoram anomaly using unique valley-based synoptic weather observations. Geophys. Res. Lett., 44(20), 10470-10478

Basnett S, Kulkarni AV and Bolch T (2013) The influence of debris cover and glacial lakes on the recession of glaciers in Sikkim Himalaya, India. J. Glaciol., 59(218), 1035-1046

Benn DI and Lehmkuhl F (2000) Mass balance and equilibrium-line altitudes of glaciers in high-mountain environments. Quat. Int., 66, 15-29

Bhambri R and Bolch T (2009) Glacier mapping: a review with special reference to the Indian Himalayas. Prog. Phys. Geogr., 33(5), 672-704

Bhambri R, Bolch T, Chaujar RK and Kulshreshtha SC (2011) Glacier changes in the Garhwal Himalaya, India, from 1968 to 2006 based on remote sensing. J. Glaciol., 57(203), 543-556

Bhambri R, Bolch T and Chaujar RK (2012) Frontal recession of Gangotri Glacier, Garhwal Himalayas, from 1965 to 2006, measured through high- resolution remote sensing data. Curr. Sci., 102(3), 1462-1466

Bhambri R, Hewitt K, Kawishwar P and Pratap B (2017) Surge-type and surge-modified glaciers in the Karakoram. Sci. Rep., 7(1), 1-14, (doi:10.1038/s41598-017-15473-8)

Bhattacharya A and 5 others (2016) Overall recession and mass budget of Gangotri Glacier, Garhwal Himalayas, from 1965 to 2015 using remote sensing data. J. Glaciol., 62(236), 1115-1133

Bhutiyani MR, Kale VS and Pawar NJ (2007) Long-term trends in maximum, minimum and mean annual air temperatures across the Northwestern Himalaya during the twentieth century. Clim. Change, 85(1-2), 159-177

Bhutiyani MR, Kale VS and Pawar NJ (2010) Climate change and the precipitation variations in the northwestern Himalaya: 18662006. Int. J. Climatol., 30(4), 535-548

Birajdar F, Venkataraman G, Bahuguna I and Samant H (2014) A revised Glacier Inventory of Bhaga Basin Himachal Pradesh, India: current status and recent Glacier variations. ISPRS Ann. Photogramm. Remote Sens. Spat. Inf. Sci., II-8(December), 37-43

Bolch T, Buchroithner M, Pieczonka T and Kunert A (2008) Planimetric and volumetric glacier changes in the Khumbu Himal, Nepal, since 1962 using Corona, Landsat TM and ASTER data. J. Glaciol., 54(187), 592-600

Bolch T, Menounos B and Wheate R (2010a) Landsat-based inventory of glaciers in western Canada, 1985-2005. Remote Sens. Environ., 114(1), 127-137

Bolch T and 7 others (2010b) A glacier inventory for the western Nyainqentanglha range and the Nam Co basin, Tibet, and glacier changes 1976-2009. Cryosphere, 4(3), 419-433

Bolch T and 11 others (2012) The state and fate of Himalayan Glaciers. Science, 336(6079), 310-314 
Brahmbhatt RM and 6 others (2017) Significance of glacio-morphological factors in glacier retreat: a case study of part of Chenab basin, Himalaya. J. Mt. Sci., 14(1), 128-141

Brun F, Berthier E, Wagnon P, Kääb A and Treichler D (2017) A spatially resolved estimate of high mountain Asia glacier mass balances from 2000 to 2016. Nat. Geosci., 10(9), 668673

Chand P and Sharma MC (2015) Glacier changes in the Ravi basin, North-Western Himalaya (India) during the last four decades (1971-2010/13). Glob. Planet. Change, 135, 133-147

Chudley TR, Miles ES and Willis IC (2017) Glacier characteristics and retreat between 1991 and 2014 in the Ladakh range, Jammu and Kashmir. Remote Sens. Lett., 8(6), 518-527

Dash SK, Jenamani RK, Kalsi SR and Panda SK (2007) Some evidence of climate change in twentieth-century India. Clim. Change, 85(3-4), 299-321

Dobhal DP, Mehta M and Srivastava D (2013) Influence of debris cover on terminus retreat and mass changes of Chorabari Glacier, Garhwal region, central Himalaya, India. J. Glaciol., 59(217), 961-971

Fischer M, Huss M, Barboux C and Hoelzle M (2014) The new Swiss Glacier Inventory SGI2010: relevance of using high-resolution source data in areas dominated by very small glaciers. Arctic, Antarct. Alp. Res., 46(4), 933-945, (doi:10.1657/1938-424646.4.933)

Frey H, Paul F and Strozzi T (2012) Compilation of a glacier inventory for the western Himalayas from satellite data: methods, challenges, and results. Remote Sens. Environ., 124, 832-843

Gardelle J, Berthier E and Arnaud Y (2012) Slight mass gain of Karakoram glaciers in the early twenty-first century. Nat. Geosci., 5(5), 322-325

Garg PK, Shukla A, Tiwari RK and Jasrotia AS (2017a) Assessing the status of glaciers in part of the Chandra basin, Himachal Himalaya. A multiparametric approach. Geomorphology, 284, 99-114

Garg PK, Shukla A and Jasrotia AS (2017b) Influence of topography on glacier changes in the central Himalaya, India. Glob. Planet. Change, 155(July), 196-212

Granshaw FD and Fountain AG (2006) Glacier change (1958-1998) in the North cascades National Park Complex. J. Glaciol., 52 (177), 251-256

Haeberli W, Bosch H, Scherler K, Ostrem C and Wallen CC (1989) World glacier inventory status. IAHS, Willingford (doi: 10.7265/ N5/NSIDC-WGI-2012-02).

Hewitt K (2005) The Karakoram anomaly? Glacier expansion and the 'Elevation Effect,' Karakoram Himalaya. Mt. Res. Dev., 25 (4), 332-340

Hewitt K (2011) Glacier change, concentration, and elevation effects in the Karakoram Himalaya, upper Indus basin. Mt. Res. Dev., 31(3), 188-200

Hubbard B and Glasser NF (2005) Field techniques in glaciology and glacial geomorphology, 1st Edn John Wiley \& Sons, West Sussex

Immerzeel WW, van Beek LPH and Bierkens MFP (2010) Climate change will affect the Asian water towers. Science, 328(5984), 1382-1385

Kääb A, Berthier E, Nuth C, Gardelle J and Arnaud Y (2012) Contrasting patterns of early twenty-first-century glacier mass change in the Himalayas. Nature, 488(7412), 495-498

Kalnay E and 21 others (1996) The NCEP/NCAR 40-year reanalysis project. Bull. Am. Meteorol. Soc., 77(3), 437-471

Kamp U, Byrne M and Bolch T (2011) Glacier fluctuations between 1975 and 2008 in the greater Himalaya range of Zanskar, Southern Ladakh. J. Mt. Sci., 8(3), 374-389

Kraaijenbrink P and 5 others (2016) Seasonal surface velocities of a Himalayan glacier derived by automated correlation of unmanned aerial vehicle imagery. Ann. Glaciol., 57(71), 103-113

Kulkarni AV (2010) Monitoring Himalayan cryosphere using remote sensing techniques. J. Indian Inst. Sci., 90, 457-469
Kulkarni AV and Alex S (2003) Estimation of recent glacial variations in Baspa basin using remote sensing technique. J. Indian Soc. Remote Sens., 31(2), 81-90

Kulkarni AV, Dhar S, Rathore BP, Govindha RKB and Kalia R (2006) Recession of Samudra Tapu glacier, Chandra river basin, Himachal Pradesh. J. Indian Soc. Remote Sens., 34(1), (doi: 10.1007/BF02990745)

Kulkarni AV and 6 others (2007) Glacial retreat in Himalaya using Indian remote sensing satellite data. Curr. Sci., 92, 69-74

Mayewski PA and Jeschke PA (1979) Himalayan and transHimalayan Glacier fluctuations since AD 1812. Arct. Alp. Res., 11(3), 267-287

Murtaza KO and Romshoo SA (2016) Recent glacier changes in the Kashmir Alpine Himalayas, India. Geocarto Int., 6049 (May), 1-18

Nagai H, Fujita K, Nuimura T and Sakai A (2013) Southwest-facing slopes control the formation of debris-covered glaciers in the Bhutan Himalaya. Cryosphere, 7, 1303-1314

Negi HS, Saravana G, Rout R and Snehmani (2013) Monitoring of great Himalayan glaciers in Patsio region, India using remote sensing and climatic observations. Curr. Sci., 105(10), 13831392

Nuimura T and 12 others (2015) The GAMDAM glacier inventory: a quality-controlled inventory of Asian glaciers. Cryosphere, 9(3), 849-864

Owen LA and 5 others (1996) The quaternary glacial history of the Lahul the quaternary glacial history of the Lahul Himalaya, Northern India. J. Quat. Sci., 11(1), 25-42

Pandey P and Venkataraman G (2013) Change in glaciers in Chandra-Bhaga bain, Himachal Himalaya, India, between 1980 and 2010 measured using remote sensing. Int. J. Remote Sens., 34(15), 5584-5597

Patel LK, Sharma P, Fathima TN and Thamban M (2018) Geospatial observations of topographical control over the glacier retreat, Miyar basin, Western Himalaya, India. Environ. Earth Sci., 77 (5), 1-12

Paul F, Huggel C, Kääb A, Kellenberger T and Maisch M (2002) Comparison of TM-derived Glacier areas with higher resolution data sets. EARSeL eProc., 2, 15-21

Paul $\mathrm{F}$ and 9 others (2009) Recommendations for the compilation of glacier inventory data from digital sources. Ann. Glaciol., 50(53), 119-126

Paul F and 19 others (2013) On the accuracy of glacier outlines derived from remote-sensing data. Ann. Glaciol., 54(63), 171-182

Pfeffer WT and 75 others (2014) The Randolph glacier inventory: a globally complete inventory of glaciers. J. Glaciol., $60(221)$, 537-552

Pratap B, Dobhal DP, Mehta M and Bhambri R (2015) Influence of debris cover and altitude on glacier surface melting: a case study on Dokriani Glacier, central Himalaya, India. Ann. Glaciol., 56(70), 9-16

Racoviteanu AE, Williams MW and Barry RG (2008) Optical remote sensing of glacier characteristics: a review with focus on the Himalaya. Sensors, 8, 3355-3383

Racoviteanu AE, Paul F, Raup B, Khalsa SJS and Armostrong R (2009) Challenges and recommendations in mapping of glacier parameters from space: results of the 2008 GLIMS workshop. Ann. Glaciol., 50(53), 53-69.

Raina VK and Srivastava D (2008) Glaciers atlas of India, 1st Edn. Bangalore: Geological society of India.

Rajbhandari R, Shrestha AB, Kulkarni A, Patwardhan SK and Bajracharya SR (2014) Projected changes in climate over the Indus river basin using a high resolution regional climate model (PRECIS). Clim. Dyn., 44(1-2), 339-357

Rashid I, Romshoo SA and Abdullah T (2017) The recent deglaciation of Kolahoi valley in Kashmir Himalaya, India in response to the changing climate. J. Asian Earth Sci., 138 (October), 38-50 
Raup B and 11 others (2007) Remote sensing and GIS technology in the Global Land Ice Measurements from Space (GLIMS) project. Comput. Geosci., 33(1), 104-125

Salerno F and 6 others (2017) Debris-covered glacier anomaly? Morphological factors controlling changes in the mass balance, surface area, terminus position, and snow line altitude of Himalayan glaciers. Earth Planet. Sci. Lett., 471, 1931

Scherler D, Bookhagen B and Strecker MR (2011a) Spatially variable response of Himalayan glaciers to climate change affected by debris cover. Nat. Geosci., 4(1), 1-4

Scherler D, Bookhagen B and Strecker MR (2011b) Hillslope-glacier coupling: the interplay of topography and glacial dynamics in high Asia. J. Geophys. Res., 116(F02019), 1-21

Schmidt S and Nüsser M (2009) Fluctuations of Raikot glacier during the past 70 years: a case study from the Nanga Parbat massif, northern Pakistan. J. Glaciol., 55(194), 949-959

Schmidt S and Nüsser M (2012) Changes of high altitude glaciers from 1969 to 2010 in the trans-Himalayan Kang Yatze Massif, Ladakh, No. Arctic Antarct. Alp. Res., 44(1), 107-121

Schmidt S and Nüsser M (2017) Changes of high altitude glaciers in the trans-Himalaya of Ladakh over the past five decades (1969-2016). Geosciences (Basel), 7(27), 469-506
Sharma S and 5 others (2016) Factors responsible for driving the glaciation in the Sarchu Plain, eastern Zanskar Himalaya, during the late quaternary. J. Quat. Sci., 31(5), 495-511

Sharma P and 5 others (2016) Role of debris cover to control specific ablation of adjoining Batal and Sutri Dhaka glaciers in Chandra basin (Himachal Pradesh) during peak ablation season. J. Earth Syst. Sci., 125(3), 459-473

Shehmani, Dharpure JK, Kochhar I, Ram RPH and Ganju A (2015) Analysis of snow cover and climatic variability in Bhaga basin located in western Himalaya. Geocarto Int., 6049(May 2016), 1-14

Shekhar MS, Chand H, Kumar S, Srinivasan K and Ganju A (2010) Climate-change studies in the western Himalaya. Ann. Glaciol., 51(54), 105-112

Shukla A, Ali I, Hasan N and Romshoo SA (2017) Dimensional changes in the Kolahoi glacier from 1857 to 2014. Environ. Monit. Assess., 189(1), 1-18

Svoboda F and Paul F (2009) A new glacier inventory on southern Baffin Island, Canada, from ASTER data: I. Applied methods, challenges and solutions. Ann. Glaciol., 50(53), 11-21

Tucker CJ, Grant DM and Dykstra JD (2004) NASA's global orthorectified Landsat data set. Photogramm. Eng. Remote Sens., 70 (3), 313-322

Yadav RR, Park WK, Singh J and Dubey B (2004) Do the western Himalayas defy global warming? Geophys. Res. Lett., 31(17), 1-5

MS received 9 February 2018 and accepted in revised form 24 September 2018; first published online 4 December 2018 